\title{
Impartiality of the Speaker:
}

\section{Politics versus Convention in New Brunswick's $55^{\text {th }}$ Legislature}

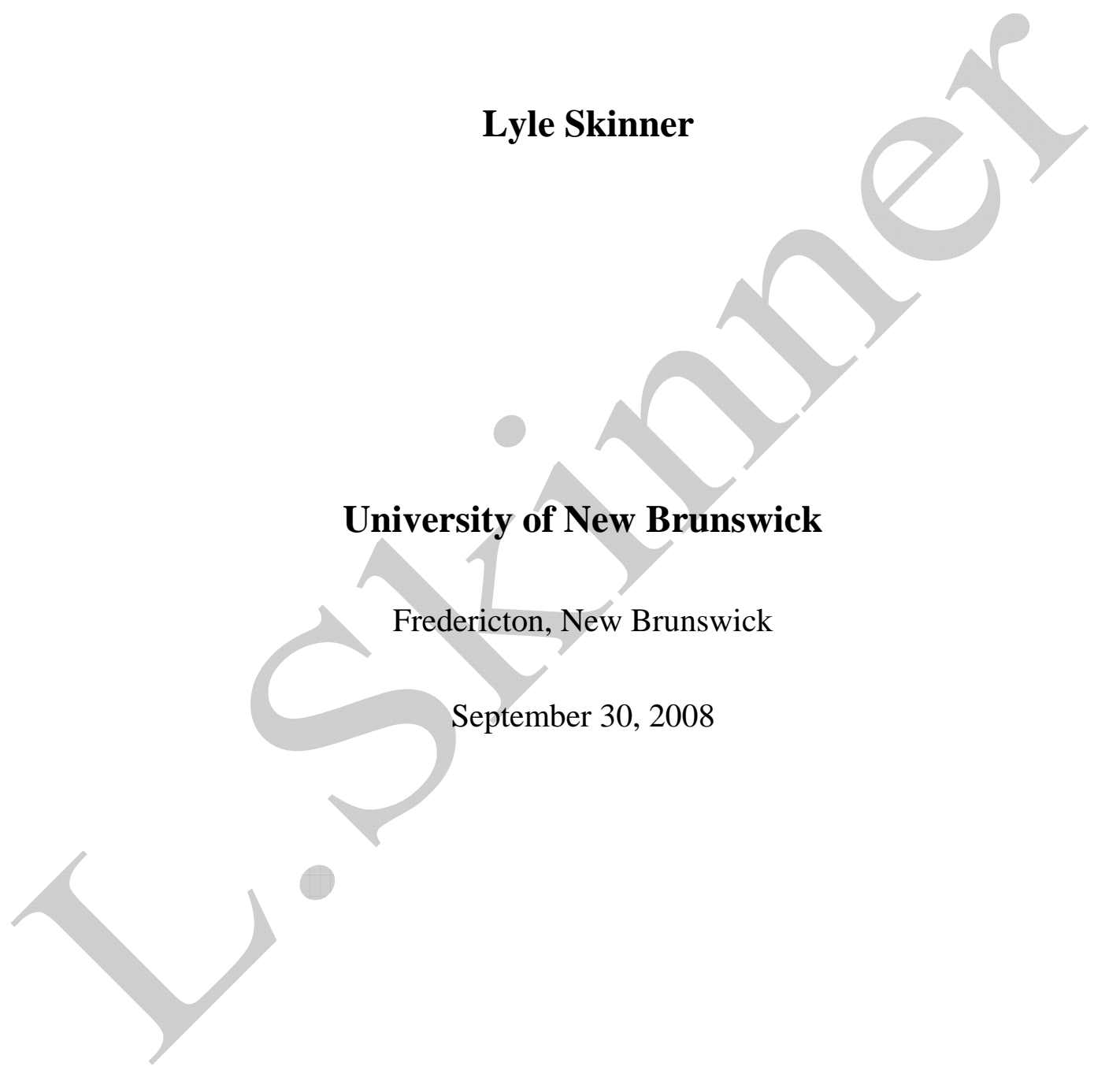




\begin{abstract}
This paper will examine the nature of Speaker impartiality within the British Parliamentary system by examining the political involvement and the casting vote of Speakers. This will attempt to historically contextualize the role of the Speaker in the province of New Brunswick and explain the institutional circumstances of the unusual conduct of Speakers Bev Harrison and Michael 'Tanker' Malley during the third session of the 55th Legislative Assembly. This paper argues that the source of this irregularity was the close seat count between opposition and government members. This issue illustrates the difficulties of smaller Legislative Assemblies reaching the convention established by the British Parliament respecting the impartiality of a Speaker where a Speaker is apolitical, thereby divorced from partisan politics. In the British convention, which serves as the fount of parliamentary practice, the Speaker refrains from any active political involvement, and in return the Speaker is uncontested in upcoming parliamentary elections.
\end{abstract}




\section{ACKNOWLEDGEMENTS}

This thesis could not have been written without the grateful assistance of Bev Harrison, a former Speaker of the New Brunswick Legislative Assembly and current MLA for Hampton Kings. His knowledge of British Constitutional history and parliamentary tradition was invaluable in my research. 


\section{TABLE OF CONTENTS}

WITH HONOURS DISTINCTION IN POLITICAL SCIENCE AND HISTORY ....................1

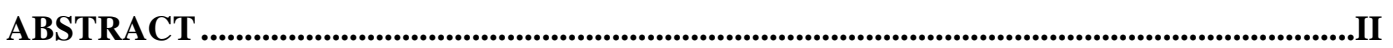

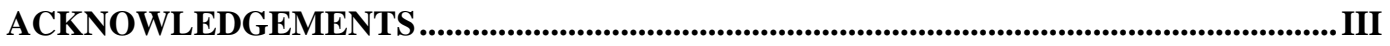

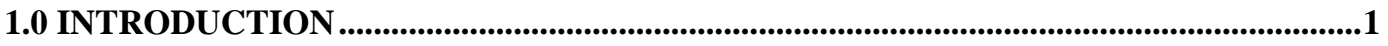

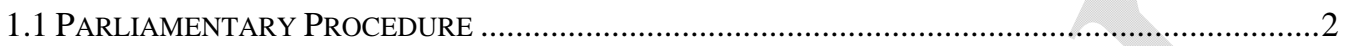

2.0 THE OFFICE OF THE SPEAKER.....................................................................................12

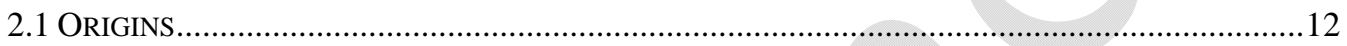

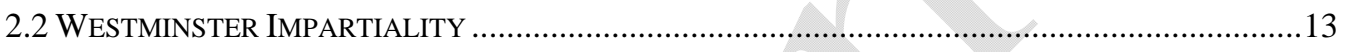

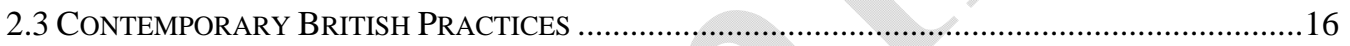

2.4 A New BRUnSwick ReVolution: PARTiality in the Colonial AsSEMBly .......................19

3.0 THE POLITICS OF NEW BRUNSWICK ................................................................................23

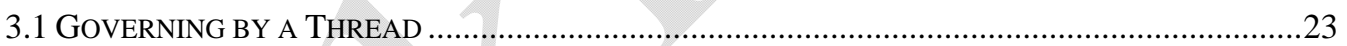

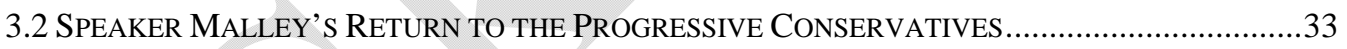

4.0 NEW BRUNSWICK PRECEDENTS OF IMPARTIALITY ..................................................42

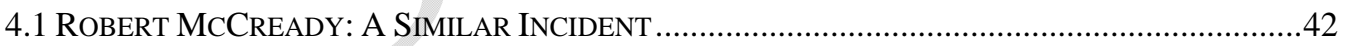

4.2 SPEAKER DYSART: THE PRECEDENT FOR IMPARTIALITY .......................................................50

5.0 THE CASTING VOTE ..........................................................................................................58

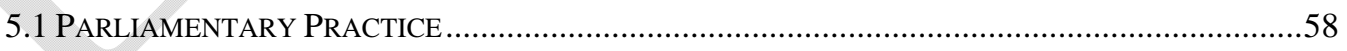

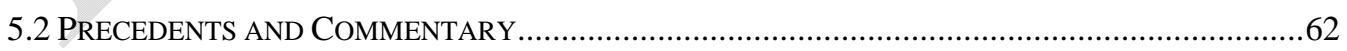

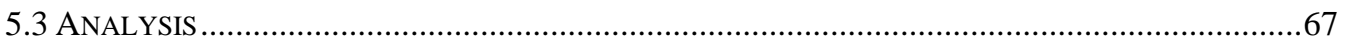

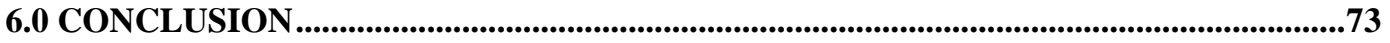

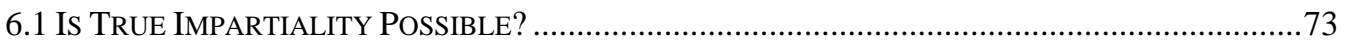

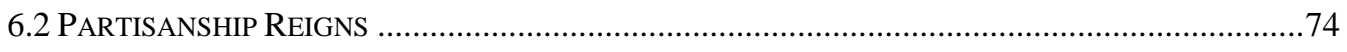

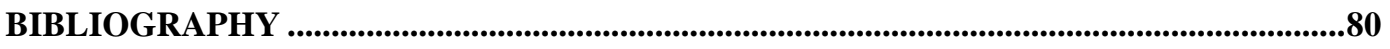


WORKS CITED.

PART III - THE FIRST MEETING OF THE HOUSE AND THE ELECTION OF A SPEAKER

PART IV — POWERS AND DUTIES OF THE SPEAKER AND OFFICERS OF THE HOUSE .90

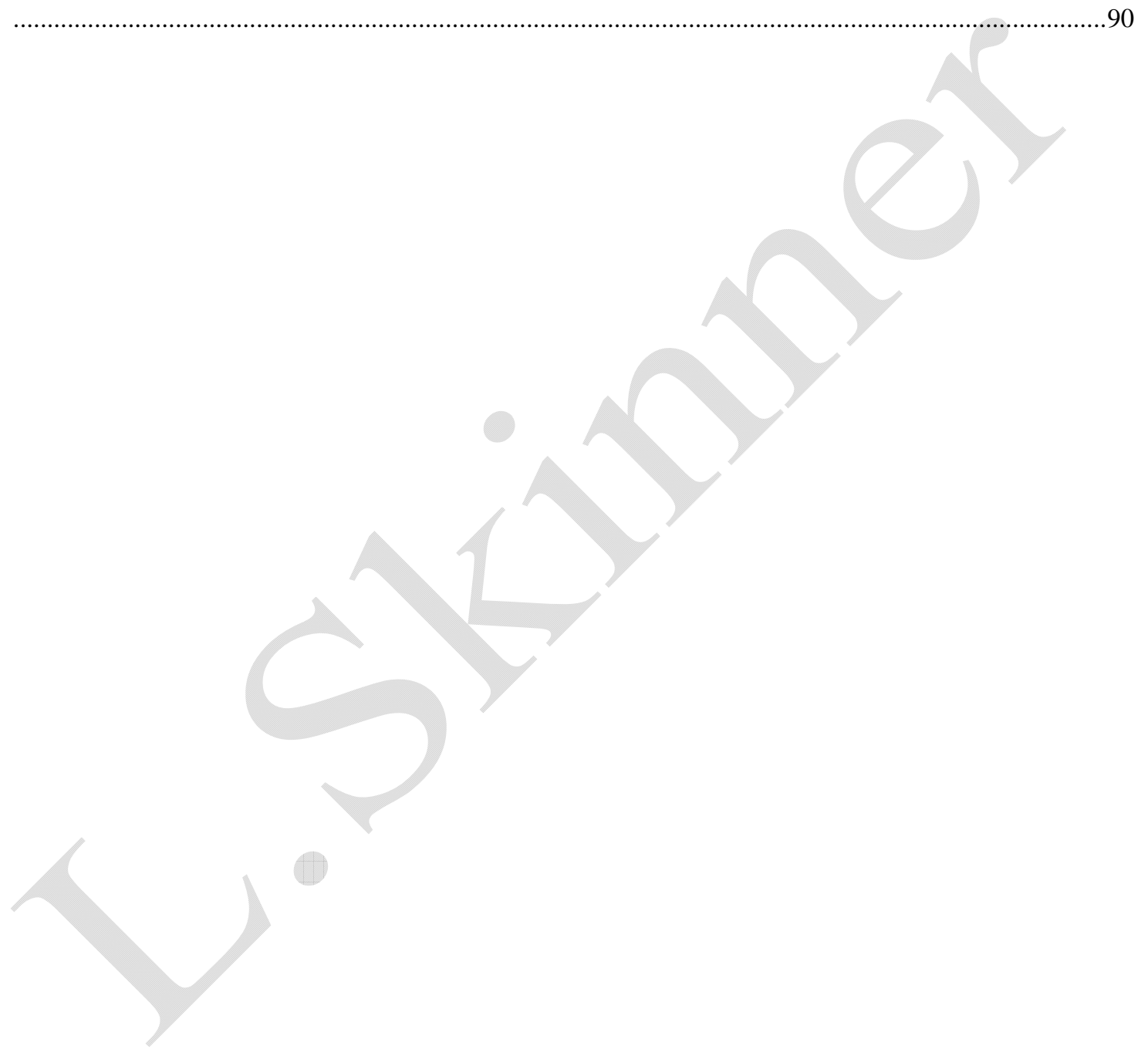


The chief characteristics attaching to the Office of Speaker in the House of Commons are authority and impartiality. ${ }^{1}$

\subsection{INTRODUCTION}

The third session of the $55^{\text {th }}$ Legislative Assembly of the province of New Brunswick was one of the most controversial sessions in the province's history. The political behaviour of Progressive Conservative Premier Bernard Lord's one seat majority government contrasted sharply with the Commonwealth parliamentary conventions. The role of the Speaker necessitates a certain degree of removal from dominate political issues in order to adhere to the above convention stated by the British procedural manual Erskine May's Treatise on the Law, Privileges, Proceedings, and Usage of Parliament, henceforth May's, to ensure equitable debate. There is a congruent relationship between the authority and impartiality of the Speaker; the more neutral a presiding officer is, the more authority is bestowed upon the Speaker. The Speaker is bound to protect the rights of the minority of members in Parliament from abuse by the majority. To become partial may infringe on the capacity of the Speaker to ensure debate is fair. However, being partisan does not necessarily convey the same meaning as being partial.

This paper argues that the political practices of New Brunswick do not adhere to the British conventions of impartiality. The political traditions and the size of the New Brunswick Legislative Assembly make it considerably difficult for the Speaker to be both impartial and non-partisan. Lord's government utilized the Office of Speaker as a means of political survival by resorting to the discretionary powers of the chair to preserve his 
government and ensure the passage of governmental policies during instances of tie votes. In this manner, the actions of Speakers Bev Harrison and Michael 'Tanker’ Malley existed under a heightened sense of public scrutiny and raised the direct question of what constitutes acceptable conduct by Speakers of the Legislative Assembly. For Speaker Harrison, there was controversy surrounding his exercising of the Speaker's casting vote where allegations were made that he deviated from parliamentary custom. For Speaker Malley, substantive criticism occurred from his overt politicization of the Office of Speaker. This being stated, the actions of Speaker Harrison and Malley must be examined within the greater political environment of a one seat majority government and should be analyzed with caution in formulating future precedents.

\subsection{Parliamentary Procedure}

In order to understand the events that transpired during the $55^{\text {th }}$ Legislative Assembly of New Brunswick, one needs to appreciate the constitutional framework of New Brunswick with specific comprehension of the province's legislative branch. New Brunswick inherited its constitutional basis from the British parliamentary system of governance. However, such a statement is insufficient when describing the framework of New Brunswick's constitution. When one asks the question "What is the constitution of New Brunswick?” the answer is more complex than at first glance. New Brunswick does 
not have a sole document entitled "The Constitution of New Brunswick"; that distinction is reserved solely to the province of British Columbia. ${ }^{2}$ Nor is the basis for New Brunswick’s constitution derived from a series of legislation similar to the twin circumstances of Ontario or Québec. As a result of its long existence, New Brunswick’s constitution is a myriad of documents ranging from the familiar, the Constitution Act, 1867, to more obscure Imperial Orders in Council. Yet, an examination of the Constitution Act, 1867 provides an insufficient basis to determine the structure of New Brunswick’s legislative branch. In fact, the sole mention of the Legislature is under section 88:

The Constitution of the Legislature of each of the Provinces of Nova Scotia and New Brunswick shall, subject to the Provisions of this Act, continue as it exists at the Union until altered under the Authority of this Act. $^{3}$

The document that provides the founding basis for the province's legislative branch is an obscure 1784 Order-in-Council (Imp) establishing Province. The Order created the entire constitutional framework for the province with the sole sentence: "That the Civil Constitution of the Governments to be Erected should be as analogous to that of Nova Scotia, as circumstances will admit...” ${ }^{4}$ This implies that the fount of New Brunswick’s constitutional structure derived from the province of Nova Scotia, which itself is modelled after the parliament of Westminster. Therefore, the traditions and customs of the British Parliament, specifically the House of Commons, were transferred to New Brunswick’s Legislative Assembly with a certain degree of minor variation. It is 
important to stress that New Brunswick’s legislative branch was established in 1784, and over the course of 200 years evolved asynchronously with Westminster. The British Parliament will always be regarded as "the mother of all parliaments", but that does not necessarily imply each individual deliberative body, which derives its legacy from Britain will be identical to Britain with respect to its manner of conduct. This is an important consideration when analyzing the legislative practices of New Brunswick as it cannot be compared to Westminster without a greater understanding of the convention or practice being analyzed.

Within Parliament there are two distinct categories of conventions: procedure and practices. In a similar aspect to the distinction between written and unwritten constitutions, parliamentary procedure consists of agreed upon manners of conduct governing the operation of the legislative branch of government. These agreements are explicitly codified in texts known as the Standing Orders, or, in New Brunswick, the Standing Rules of the Legislative Assembly of New Brunswick. ${ }^{5}$ At their core, the Standing Rules are merely legislative motions that are not legally binding upon the Parliament, and can be altered, or dispensed with entirely, by majority resolution of the House. Moreover, the rules can be temporarily suspended with the unanimous consent of the House. The procedural responsibility of the New Brunswick Speaker is to enforce the Standing Rules.

When an individual examines the proceedings of the Legislative Assembly, the Standing Rules are insufficient to explain its integral operations. In these instances, the determination of how the Assembly should proceed with an issue falls under the 
nomenclature of parliamentary practice. Parliamentary practice relies upon the substantive bulk of precedents or actions from previous assemblies. Standing Rule 6 grants the Speaker the authority to decide upon "all cases not provided for in [the Legislative Assembly] Standing Rules" as determined by the "usage and precedents of the House and the parliamentary tradition in New Brunswick and other jurisdictions.”* Standing Rule 13 highlights the power of the Speaker by declaring that when the Speaker decides upon a point of order, "No debate may be permitted on any such decision, and no such decision shall be subject to an appeal to the House.”6 This means that the ruling of the Speaker is final and then becomes incorporated as part of the 'usage and precedents' of the Assembly.

Normally there is a self regulating behaviour within the Assembly that prevents substantial violations of its Standing Rules or customs. With respect to parliamentary procedure, during times of majority governments, the governing party is theoretically capable of controlling debate with impunity for the duration of the Assembly, and could modify the Standing Rules as it sees fit. These circumstances would effectively limit the ability of the opposition to fulfill its role of opposing the policies of the government.

\footnotetext{
* Please refer to Appendix A for an exhaustive listing of relevant Standing Rules of the New Brunswick Legislative Assembly
} 
Parliamentary practice is equally susceptible to abuse as one individual (the Speaker) is capable of altering the customs of the House by providing a ruling that is inconsistent with previously established practices.

Sir Ivor Jennings in his treatise The Law and the Constitution described three principle tenets for the establishment of constitutional conventions as the follows:

We have to ask ourselves three questions: first, what are the precedents, secondly, did the actors in the precedents believe that they were bound by a rule; and thirdly, is there a reason for the rule? A single precedent with a good reason may be enough to establish a rule. A whole string of precedents will be of no avail, unless it is perfectly certain that the persons concerned regarded them[selves] as bound by it.?

With the above principles, Jennings describes a process to determine the existence of a constitutional convention using the following criteria: there must be historical precedents; the individuals involved in these precedents feel they were bound by a rule; lastly, is there a rational reason for the existence of the rule. To rephrase, if a convention does not logically conform to the political realities of the day, there is a propensity to suggest the abandonment of the rule. However, the convention of Speaker impartiality is so integral to the workings of the Westminster parliamentary system that complete abandonment of the convention would create dysfunction within parliament.

Constitutional theorist Andrew Heard in his work Canadian Constitutional Conventions proposes an approach to understanding conventions, which abandons the 
traditional dichotomous understanding of constitutional conventions. Most scholars follow the opinion of British theorist A.V Dicey by contrasting conventions in a negative context against legal statute. In the words of Dicey, conventions are "customs, practices, maxims or precepts which are not enforced or recognized by the courts, make up a body not of laws, but of constitutional or political ethics...”8 Heard counters that there are multivariate categories of conventions: fundamental conventions, which are integral to the operational framework of the country. Meso conventions are subordinated to a general rule; conventions in this category can manifest themselves in reality with a varying degree of permutation. Semi conventions follow a 'distant' principle; however, breaching a semi convention would not cause a fundamental change to the constitution. Furthermore Heard describes a category consisting of infra-conventions where there is generally no agreed upon consensus of how a political actor should behave. ${ }^{9}$

Under Heard's doctrine, the convention of Speaker impartiality falls under the classification of a meso convention. Speaker impartiality conforms to the status of a meso convention as there exists no agreed upon consensus across parliamentary jurisdictions as to the degree of impartiality. Furthermore, Speaker impartially is subordinated to the concept of responsible government. The maintaining of a properly functioning 
Legislative Assembly, which enables responsible government, hinges upon the Speaker to adjudicate in a fair manner between those who support and oppose the government. ${ }^{\dagger}$

In most circumstances, legislators do not greatly infringe upon the self governing nature of parliamentary assemblies despite what Jennings describes that parliamentary procedure is a “conflict between Her Majesty’s Government and Her Majesty’s Opposition.” ${ }^{10}$ The manner of conduct in the Assembly is the interplay between a government's right to govern so long as it maintains the confidence of a majority of members in the Assembly, and the right of those members who do not support the government to publicly scrutinize its actions. Jennings further writes that these conventions are adhered to because "they are part of the tradition, are reasonable, and are integral to the proper functioning of a Westminster form of parliamentary governance.”11

In the British practice, the impartiality given to the Speaker has increased the availability of discretionary powers used to enforce decorum and proper process within the House of Commons. When the Speaker rises from the Speaker's chair, all debate

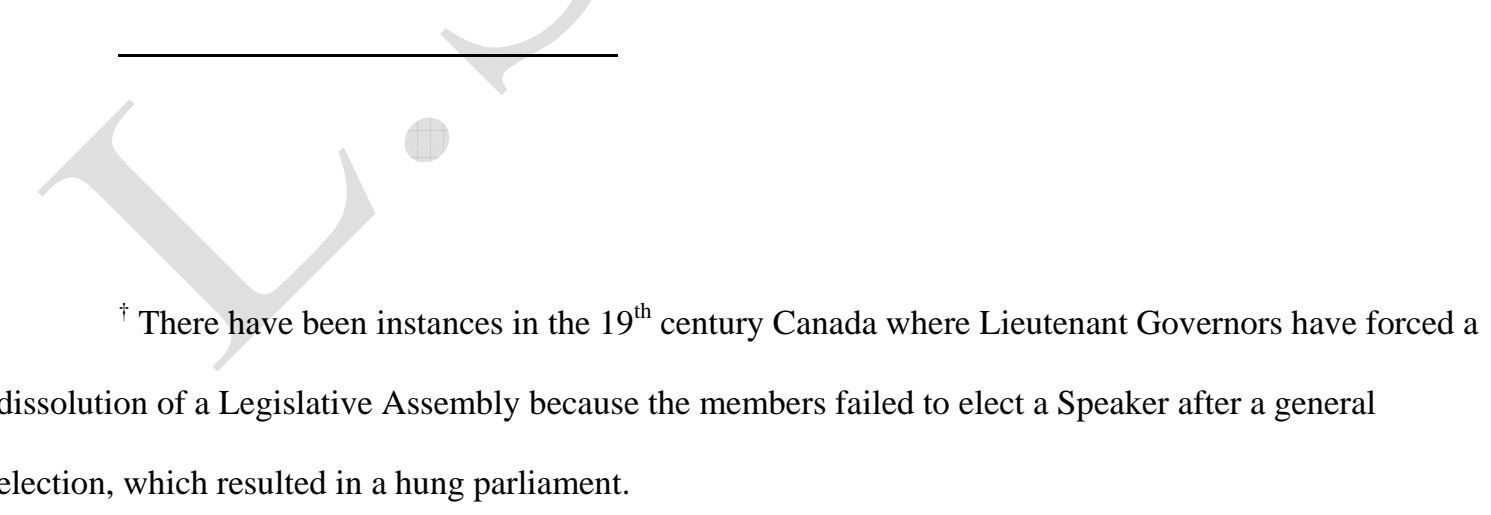


must cease, or the Speaker may utilize disciplinary actions to persuade members to resume order. A Speaker can compel members to retract statements that are deemed to be unparliamentarily. Failure of a member to withdraw their objectionable remarks may result in the Speaker naming the member, whereby the House votes on whether to remove the member for the remainder of the legislative sitting. ${ }^{12}$

In New Brunswick, the Speaker's powers are codified under the Standing Rules of the New Brunswick Legislative Assembly. A Speaker's powers are similar to those of his British counterpart. Unlike the practises of other Canadian jurisdictions the conduct of a Speaker is not subject to appeal. A Speaker's actions cannot be criticized during the regular course of debate. A member would face reprimand by the Speaker's discretionary powers for challenging the authority of the Speaker. The heavy handed approach in restricting the scope of challenging a Speaker's actions is necessary in order for the proper functioning of the Legislative Assembly. May's describes this as a function of the Speaker's impartiality. In a properly functioning legislative body, substantive criticism of a Speaker's actions is rare because the House places its trust in the Speaker's acting as a competent presiding officer. Essentially when the Speaker is in the chair, he or she is above politics and treats all members, regardless of political affiliation, with the same fairness and respect. 
${ }^{1}$ May, Thomas Erskine. McKay,W.R.Cranmer, Frank, Erskine May's treatise on the law, privileges, proceedings, and usage of Parliament. Uniform Title: Treatise on the law, privileges, proceedings, and usage of Parliament, 23rd ed. / editor, Sir William McKay ; assistant editors, Frank Cranmer ... [et al. ed. (London: LexisNexis UK, 2004). 220

2 British Columbia. “British Columbia: Queen’s Printer,” Constitution Act.” (Online). In Revised Statutes of British Columbia, 1996, Chapter 66. Available: http://www.qp.gov.bc.ca/statreg/stat/C/96068_01.htm [Accessed 6 May. 2008].

3 Canada, “Canada: Department of Justice,” Constitution Act, 1867 (Online) http://laws.justice.gc.ca/en/Const/c1867_e.html] [Accessed 22 July 2008]

4 New Brunswick, The revised statutes of New Brunswick, 1952, being a revision and consolidation of the public statutes of the legislature of New Brunswick, printed from the roll declared to be the revised statutes of New Brunswick, 1952, pursuant to the Revised statutes 1952 act (Fredericton: Queen's Printer for the Province, 1953), 2

${ }^{5}$ Ivor Jennings Sir, Parliament, 2d ed. (Cambridge: University Press, 1957), 70

${ }^{6}$ Jennings, 70

${ }^{7}$ Ivor Jennings Sir, The law and the constitution, 5th ed. (London: University of London Press, 1959), 136 
${ }^{8}$ Andrew David Heard, Canadian constitutional conventions : the marriage of law and politics (Toronto ; Oxford: Oxford University Press, 1991), 5

${ }^{9}$ Heard, 145

${ }^{10}$ Jennings, Parliament, 9

${ }^{11}$ Jennings, Parliament, 62

${ }^{12}$ Selwyn Lloyd Lord, Mr. Speaker, sir (London: Cape, 1976), 61 


\subsection{THE OFFICE OF THE SPEAKER}

\subsection{Origins}

The origins of the New Brunswick Speaker can be traced back to its English predecessor. Records indicate that the first individual appointed under the guise of Speaker occurred in 1377; however, the Office of Speaker dates back to a considerably earlier time. Under the monikers 'Parlour', 'Prolocutor', or 'Procurator', these individuals presided over debate in a primordial English Parliament, which conducted its proceedings in a dramatically different fashion than modern assemblies. The first known 'Speaker', Peter de Montfort, chaired debate of the 1258 'Mad Parliament'. ${ }^{13}$ The task of these medieval Speakers did not emphasize the maintaining of decorum: a task commonly associated with modern Speakers. Instead, they were servants of the Crown and served at the monarch's pleasure. Only via the remarkable actions of Speaker Lenthal during the English Civil War do the first conceptions of modern day impartially begin to emerge. Lenthal presided during the chaotic time of the English Civil War. In a heightened period of conflict the English Monarch, Charles I, stormed into Parliament demanding the whereabouts of several members of Parliament.

Speaker Lenthal, in response to the unprecedented inquires of the King responded with the following historic phrase:

May it please Your Majesty, I have neither eyes to see, nor tongue to speak in this place, but as the House is pleased to direct me, whose servant I am here; and I humbly beg Your Majesty's pardon that I cannot give any other answer than this 
to what Your Majesty is Pleased to demand of me.

The significance of Lenthal's actions cannot be understated. In one solemn act of defiance, he drastically altered the role of the Speaker. No longer was the Speaker a subservient appointee of the Crown, instead the Speaker became the embodiment of the House of Commons itself. Lenthal's comments demonstrated that the Speaker is the messenger of, and accountable to the House of Commons alone. This marked the inception of the convention that Speakers are representatives of their legislative bodies and not the Crown.

\subsection{Westminster Impartiality}

The role of the Speaker as a servant of the House of Commons did not initially imply that the Speaker refrained from participating in debate, or exercising a deliberative vote. In the $19^{\text {th }}$ century conventions were established in Westminster to heighten the level of impartiality of Speakers. Procedural scholar Joseph Redlich notes the British practice where a member who is elected as Speaker ceases "to belong to any political party; this condition precedent for the Speaker’s impartiality, his exclusion from the conflict of parties, has been an unwritten law of Parliament since the beginning of the nineteenth century." ${ }^{15}$ Redlich further observes that since this timeframe there have been 
two conventions that have been adhered to: a Speaker who does not wish to resign his seat and quit political life will be re-elected as Speaker; second, the individual will be reelected as Speaker even if his former party now comprises a minority of members in the House of Commons. ${ }^{16}$ In addition, there is a convention that political parties do not contest a Speaker's riding during a general election. This guarantee of 'safe passage' in a general election allows the British Speaker to absolve himself from the perils of partisan politics completely. The creation of the convention of Speaker impartiality can be traced to a formative moment during the mid $19^{\text {th }}$ century where British politicians, led by Sir Robert Peel, outlined a purposeful rational for depoliticizing, thereby removing the partisanship associated with British Speakers.

In 1834, the active political conduct of Speaker Manners-Sutton provoked the ire of his political adversaries. Manners-Sutton had been in communication with the Duke of Wellington in order to form a new cabinet as a result of the 1834 'dismissal' of Lord Melbourne as Conservative Prime Minister of the United Kingdom. Consequentially, Lord Melbourne opposed his re-election as Speaker citing that Manners-Sutton was biased:

I think that the Speaker of the House of Commons should not take part in political changes, and particularly not in a change which there was every reason to believe was disagreeable to the majority of the House, of which he is the servant, and which involved its dissolution. 
In the newly constituted parliament, Manners Sutton was defeated by the Whigs who installed their candidate, Charles Shaw Lefevre, as Speaker. When the Conservative Party regained power in 1841 some of its members opposed the re-election of Speaker Lefevre. Sir Robert Peel, leader of the Conservative Party, rejected the sentiments of his colleagues and supported Shaw Lefevre’s Speakership. Peel outlined five reasons which serve to encompass the rational for re-electing Shaw Lefevre:

First, I do not think it for the public advantage that the election for the Chair should necessarily be made the object of a party. Secondly, I do not think it would be just towards a Speaker who has shown himself well qualified for his office, and has in my opinion acted fairly and impartially, to reject him. Thirdly, I think that the late Speaker, if he be re-elected with the general goodwill of the House, will have greater authority and power to preserve order than a Speaker elected after a party contest. Fourthly, I do not think we have any person to propose who would appear to advantage as Speaker, all things considered, when compared with Lefevre, Fifthly, it is not a very high or satisfactory ground to allege for opposing Shaw Lefevre that the Whigs and Radicals opposed Lord Canterbury [MannersSutton]. We said it was unjust and unpolitic[sic] to oppose Lord Canterbury, and it seems to me more becoming to a great party to act upon its own principle, and even apply it against itself, than to say to its opponents, though our principle was the right one, yet by way of retaliation we will adopt yours. ${ }^{18}$

The importance of Peel's comment was significant. His leadership is indicative of a deliberative effort by the British House of Commons to change the nature of the Speakership in Westminster. In accordance with Jennings' doctrine for the establishment of conventions, there is an irrefutable reason for the establishment of the convention of depoliticizing the Office of Speaker. Peel's fifth point is the most important as it transcends normal political discourse. Peel wished to apply the convention at the expense of his party utilizing the Office of Speaker as a form of political patronage. By 'acting upon his own principle’ Peel demonstrated that politics can be conducted differently. His 
actions created the rational, transformative reasons why British Speakers exhibit the convention of impartiality, and more importantly why most British political actors respect the impartiality of the office.

\subsection{Contemporary British Practices}

British Speaker Selwyn Lloyd in his 1976 autobiography describes in detail the practices surrounding a British Speaker seeking re-election in a general election. Furthermore, his electoral experience in 1974 demonstrates the ramifications of what can occur when political parties contest a Speaker's seat in violation of the established practice. The British model is unique in the Commonwealth as it serves to demonstrate the purest form of impartiality of a Speaker who is chosen from within a parliamentary Assembly. By being devoid of a political party, the British Speaker is truly a servant of the House of Commons; however, this also poses a potential problem as a non partisan politician is materially disadvantaged in a partisan political system.

Lloyd accepted the role of Speaker in 1971 and was uncertain whether to remain in the role as Speaker should parliament continue into its full length when an election would occur in July of $1975 .{ }^{19}$ With Prime Minister Edward Heath asking the Queen to dissolve parliament on 7th February 1974, Lloyd decided to contest the upcoming election. 
Lloyd comments on the perplexing circumstances faced by him as a Speaker seeking re-election. As an independent, apolitical Member of Parliament, British precedent dictated that should he be returned to the Commons, he would continue to serve as Speaker. More puzzling for his constituents was in what capacity they were voting for Lloyd: either for him in his capacity as a Member of Parliament, or his conduct as Speaker. Lloyd indicated that a substantial amount of his constituents assumed that he would continue to serve as Speaker regardless of whether he was re-elected as a Member of Parliament. ${ }^{20}$

Lloyd cited additional confusion regarding the political contestation of his riding: since the previous election there was a substantial redistribution of his riding. The opposition Labour Party contended that because Lloyd ran in effectively a new constituency, the voters in that riding should have an opportunity to pass judgement on Speaker Lloyd. ${ }^{21}$ Despite this view by opposing parties, Lloyd considered the precedents of former Speaker Gully, a Liberal, who in 1895 faced contestation of his riding by the Conservative opposition. During a tumultuous campaign, Gully made the following pronouncement at a public meeting which embodies the British perspective on the election of a Speaker:

The first reason was that the English people were in the main lovers of fair play, and that it had struck them as being a somewhat unfair spectacle to see someone who, in the public interest, was disabled form protecting himself by the ordinary weapons of political warfare, exposed to an attack and unable to defend himself. A Speaker could not withdraw from the political arena. On the contrary, he must be a Member before he was a Speaker, but he was disarmed. It had occurred to our fathers and forefathers that it was unfair to put a man disarmed in the middle 
of a ring, and that the proper course was not to subject him to the conditions of a contest. That appeared to some people of the present day to be a quixotic piece of generosity. He hoped there would be some generosity left still in public life. ${ }^{22}$

Gully was re-elected with an increased majority of votes even though his own Liberal Party was defeated at the polls. In a manner of reconciliation, the now governing Conservatives proposed nominating Gully for re-election to the Office of Speaker.

The Labour candidate in the 1974 election claimed that it was Lloyd's duty to run as a Conservative candidate in the election as it was a "denial of a democratic right for [Lloyd] to not be opposed in a constituency of the size of Wirral.” Moreover, the Labour candidate rhetorically asked "who had laid down these rules about it being unfair to oppose the Speaker?”23 Lloyd faced additional challengers from the Liberal and Labour parties despite more senior members of both parties confiding to Lloyd that they “thoroughly disapproved of the Speaker being opposed when seeking re-election in his constituency”. Unfortunately, these members could not overrule the local riding associations. Despite the breach of British convention, Lloyd was successful in his reelection attempt where he continued to serve as Speaker until resigning in 1976. 


\subsection{A New Brunswick Revolution: partiality in the Colonial Assembly}

The actions of the first Speaker of the New Brunswick Legislative Assembly demonstrate that historically New Brunswick Speakers were susceptible to partisan influence and outright questionable conduct. Regardless of the separation of the Crown established in Britain, the subservience of the Speaker to the Crown, via the Governor, was less than clear. New Brunswick’s first Speaker, Amos Botsford, was elected in 1785 by his peers to serve as Speaker in the first Legislative Assembly of New Brunswick. Botsford continued in this capacity until his death in $1812 .{ }^{24}$ His actions during the 1802 legislative session are perhaps the most egregious and biased instances of a presiding officer in the Province of New Brunswick. At this time, Speaker Botsford was free to exercise a deliberative rather than casting vote and did so on multiple occasions. The Speaker demonstrated conduct that would be unfathomable in modern presiding bodies by issuing arbitrary Speakers Warrants detaining New Brunswick citizens for criticizing the Legislative Assembly. During one of the early Legislatures, the Legislative Assembly passed a motion citing that the Sheriff of Saint John, by giving the vacant Legislative Assembly seats to candidates who garnered a minority of votes, had "conducted himself

legally, fairly, and with impartiality."25 An individual named George Handyside, who expressed strong criticism of the Assembly's support of the Sheriff, was issued a Speaker's Warrant by Botsford and then brought before the House where he was 
“compelled to ask pardon, on his knees, for his contempt and breach of privilege.”26 Speaker Botsford then reprimanded Handyside, and discharged him after forcing Handyside to pay a fee.

Another instance of misconduct by Botsford occurred later in his tenure. ${ }^{27} \mathrm{~A}$ conflict between the Legislative Assembly and the Legislative Council over the Assembly paying appropriations in a revenue bill resulted in a majority of members refusing to attend sittings of the Assembly thereby denying the Assembly quorum. These individuals assumed that the Speaker would refrain from conducting business due to an absence of quorum. On the first day, Botsford refused convene the Assembly. Subsequently, under pressure from the Governor and his supporters, Speaker Botsford ignored the quorum requirement of 13 members, convened the Assembly, and allowed the Assembly to proceed passing the legislation even though there were only 8 members including Botsford present! ${ }^{28}$ In the words of author James Hannay, "the entire proceeding was stamped with illegality”. ${ }^{29}$

The genesis of the Speakership in New Brunswick clearly demonstrates that Speakers were inherently political and biased. The British convention of impartiality did not develop until after the creation of New Brunswick. This means that the traditions and customs of New Brunswick are distinct from Westminster, and one must be careful when comparing the British practices with New Brunswick as they are not directly analogous. 
${ }^{13}$ Philip Laundy, The office of speaker in the parliaments of the Commonwealth (London: Quiller, 1984), 11

${ }^{14}$ Laundy, 34

${ }^{15}$ Josef Redlich, The procedure of the House of Commons; a study of its history and present form. Uniform Title: Recht und Technik des englischen Parlamentarismus. English (New York: AMS Press, 1969), 132

${ }^{16}$ Redlich, 133

${ }^{17}$ Jennings, Parliament, 66

${ }^{18}$ Jennings, Parliament, 66

${ }^{19}$ Lloyd, 129

${ }^{20}$ Lloyd, 131

${ }^{21}$ Lloyd, 130 
${ }^{22}$ Laundy, 111

${ }^{23}$ Lloyd, 134

${ }^{24}$ James Hannay, History of New Brunswick (St. John: N.B., J.A. Bowes, 1909), 172

${ }^{25}$ Hannay, 182

${ }^{26}$ Hannay, 183

${ }^{27}$ Hannay, 278

${ }^{28}$ Hannay, 279

${ }^{29}$ Hannay, 279

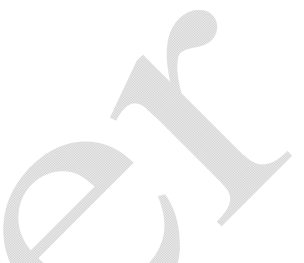




\subsection{THE POLITICS OF NEW BRUNSWICK}

\subsection{Governing by a Thread}

The Province of New Brunswick has a unicameral legislative branch known as the Legislative Assembly. With 55 members, the Assembly is one of the more overrepresented parliaments in Canada: the constituent to MLA ratio equates to approximately 14000 to 1 . This degree of representation affects the character of politics within New Brunswick, where the popularity of an individual politician contributes greatly to their electoral success. Compared to a more populous province like Ontario, or the federal government, New Brunswick remains firmly antiquated in terms of how politics is conducted. Within the Progressive Conservative Party, political corn boils, church suppers, and old fashioned electioneering have not yet been supplanted by the computerization and centralisation found in other political jurisdictions.

The population of New Brunswick is relatively dispersed within the province, meaning that there are few core areas of the province with a disproportionate amount of political influence. Unlike other provinces such as Ontario, where the core population is concentrated in the greater Toronto 905 region, prospective Premiers must cater to a diverging range of competing socio-economical interests. New Brunswick’s industrial port city of Saint John is starkly different than the agrarian potato fields of Carleton County or the fishing communities along the Acadian peninsula. 
Historically, New Brunswick is representative of one of the purest two party systems in Canada. New Brunswick governments have consistently alternated between Liberal and Progressive Conservative, with each individual government lasting at minimum two terms. With the exception of the 1987 Liberal victory where Frank McKenna's Liberal Party swept to power capturing $100 \%$ of the seats with only $60 \%$ of the popular vote, and the ensuing election which led to the brief rise of a multiparty legislature, there is a traditional practice in New Brunswick politics where bipartisan solutions to issues pertaining to the province do not occur. This creates an antagonistic situation whereby the Legislative Assembly ceases to be a deliberative Assembly and instead is used by governments to present their agenda, pass bills and request supply. Normally, opposition parties can only criticise but not constrain a government's agenda.

The consequence is that for opposition parties, creative use of parliamentary procedure serves as one of the few instances private members can use to 'frustrate' a government's legislative session. All too often a member's raising of a point of order, or bringing forward an instance of parliamentary privilege is ruled out of order by the Speaker due to the issue being political instead of procedural. Because a Speaker's rulings are not subject to debate, the issue is often dropped without controversy. However, repeated challenges of the Chair's conduct may create latent political problems. If a Speaker's rulings are challenged in a sustained manner, the perception may arise that the Speakership is being politicized.

The 9 June 2003 election reduced Progressive Conservative Premier Bernard Lord's government to the slimmest of majorities. After a near disastrous election 
campaign over the surprise ballot issue of automobile insurance, the Progressive Conservative's 44 seat majority government was reduced to a one seat majority with the party standings as follows: Progressive Conservative 28, Liberal 26, New Democratic Party 1 . This unusual seat distribution set the undercurrents for unprecedented procedural constraints on the Lord government.

When the $55^{\text {th }}$ Legislative Assembly convened, it selected Progressive Conservative MLA Bev Harrison as Speaker. With the Speaker in the chair, the 27 remaining Progressive Conservative Government members equalled the combined Liberal and New Democrat total; therefore, creating a virtual tie in voting. This meant that the traditionally rare occurrences of a Speaker exercising a casting vote in the Commonwealth became commonplace in New Brunswick.

For the first time in New Brunswick, the Legislative Assembly became a deliberative chamber necessitating the coordination and the cooperation of the Liberal and NDP parties in order for the government to pass its legislative agenda. Although Premier Lord indicated on several instances that he would continue to govern as if he had a majority government, the procedural reality of how business is conducted in the legislature made his statements political in nature. An understanding of the committee system in Westminster style legislative assemblies facilitates the discussion of the procedural realties facing the Lord government.

In order for legislation to become law in the province of New Brunswick, convention dictates that a motion passed by the Assembly requesting that a bill be read 
for a first time must be agreed upon. Commonly this process is known as first reading. Parliamentary practice is such that first reading is never refused. Provided a bill has a mover and seconder, the bill is then tabled for debate at a later point in time known as second reading.

At second reading, the Legislative Assembly then discusses the general merits of the legislation. If the Assembly agrees that the bill be read a second time, it will then proceed to either the Committee of the Whole House or if it is a piece of financial legislation, the Committee of Supply. In either case the rules of the debate are relaxed. In accordance with the Standing Rules, members are permitted to speak multiple times and at greater length. After the committee stage, a bill then proceeds to third reading to approve the legislation in its final form. If a bill passes third reading it receives royal assent.

Because the Speaker does not attend either Committee of the Whole or Supply, the deputy Speaker is appointed as the chairman of the committee. Traditionally the chairman is appointed from the governing party thus reducing the government's majority by an additional seat in committee. As the Committee of the Whole is only a creation of the Legislative Assembly, it is not indicative of the will of the Legislative Assembly proper. These committees can only provide the House with recommendations of how to proceed with legislation. The House is free to either concur or reject the committee's recommendation.

During the $55^{\text {th }}$ Legislative Assembly, the government operated as a de facto 
minority government within the Committee of the Whole and Committee of Supply. Although opposition party members could not defeat the government directly with an explicit motion of non confidence or via refusing supply, the minority situation in committee enabled opposition members to exploit a procedural loophole within the Standing Rules of the New Brunswick Legislative Assembly. At the time, there existed no limit of debate within these committees meaning that if pressed, opposition parties could allow for an indefinite amount of debate within the committee creating a legislative deadlock and possibly an indirect withholding of supply. In 2003, the Conservative government, cognisant of its precarious situation in committee, entered into a pairing arrangement with the opposition. The agreement stipulated that the committee chairs would be paired with the opposition to ensure that the government would have a majority vote in these committees. ${ }^{30}$

In these circumstances, one can characterize Bernard Lord's second term as a struggle to gain an additional seat for his majority government. Initially his strategy involved enticing political opponents with government appointments, thus creating temporary vacancies within the Legislative Assembly. During the second session of the $55^{\text {th }}$ Legislative Assembly, Lord appointed former interim Liberal Leader and MLA for Shediac-Cap-Pelé, Bernard Richard, as the Provincial Ombudsman thereby temporarily increasing the government's majority by one seat until the ensuing by-election that returned a Liberal MLA to the Legislative Assembly.

In late 2005, Bernard Lord appointed NDP Leader and MLA for Saint John Harbour, Elizabeth Weir, as the President and CEO of the Energy Efficiency and 
Conservation Agency. Weir's absence from the Assembly temporarily provided the Progressive Conservatives a two seat majority government. Unlike the situation pertaining to Richard, Lord quickly called a by-election for Saint John Harbour with the aim of having the high profile deputy mayor Michelle Hooten elected as the Progressive Conservative MLA. The Liberals contested the nomination with local doctor Ed Doherty. For Lord, this by-election served as a high stakes gambit: a successful win would result in a two seat majority government, but a loss would further constrain the Lord government. The additional seat would remove much of the procedural difficulties found in a one seat majority government. Electoral defeat of Hooten by the Liberal Party would decrease the likelihood of bipartisan cooperation, as the NDP would no longer be represented within the Legislature. The electoral results created in an upset for the Progressive Conservative Party with Liberal candidate Ed Doherty winning with 55 percent of the popular vote. ${ }^{31}$ To quote Liberal Leader Shawn Graham’s assessment of the electoral situation: “As it stands right now, there are 26 Liberals in the House and with the addition of Dr. Ed Doherty, it will bring us up to 27 and make politics in New Brunswick much more interesting.,32

In February 2006, Premier Bernard Lord orchestrated a cabinet shuffle appointing Speaker Bev Harrison as Minister of Supply and Services. At this time Lord stated that it was his intention that Tony Huntjens serve as a possible candidate for Speaker of the Legislative Assembly. Furthermore, Lord indicated that Progressive Conservative MLA for Miramichi Bay de Vin, Michael Malley would serve as government whip. For Malley, his exclusion from Cabinet prompted him to unexpectedly quit the Progressive 
Conservative caucus.

According to Malley’s letter of resignation, he cites that he was dissatisfied with the direction of the Progressive Conservative government, and that he felt that the Miramichi region was being ignored by Premier Lord due to the government closing hospitals and not resolving an economic downturn within Miramichi. Malley explained that "If we can find money for the mill in Nackawic and golf courses in Dieppe, we can do a lot more for Miramichi." ${ }^{33}$ For this reason Malley declared that he would now serve as an independent member of the Legislative Assembly, and he subsequently quit the Progressive Conservative caucus. However, according to Premier Lord, Malley’s departure from the Progressive Conservative caucus was significantly more controversial than claimed by Malley.

Lord held a press conference on Saturday, February 18 in response to Malley’s departure. There, he alleged that Malley left the Progressive Conservatives due to a personal disappointment of not being appointed to Cabinet in the recent shuffle. Furthermore, Lord contended that Malley made a series of unreasonable demands of the government such as receiving more money for Malley’s constituency office, allowing Malley to have a special assistant, and appoint a friend to become a judge in Miramichi. ${ }^{34}$ Lord statement to the media was quite frank: "While I understand his personal disappointment, I cannot and will not put his personal interests or interests of any other individual ahead of the interest of the Province of New Brunswick.”35

With Malley as an independent, the legislative composition became 27 
Progressive Conservatives, 26 Liberals and 2 independents as Liberal MLA Frank Branch left his caucus due to an investigation pertaining to his conduct as manager of the North Shore Forest Products Marketing Board. This situation meant that Lord became the first New Brunswick Premier to have a minority government. At this juncture, Lord acknowledged that his government could fall on April $7^{\text {th }}$, 2006 when the Legislative Assembly would vote on the government's budget.

When the House reconvened on March 28, Malley was the only candidate who stood for election as Speaker. It is apparent that Malley’s selection as Speaker was done for the survival of the Lord government, rather than the House expressing a desire for Malley to serve as Speaker based on his competency. Although the House is free to elect its own Speaker, the leaders of political parties can influence their caucuses to select a specific candidate for Speaker. Since Lord previously expressed his desire for Tony Huntjens to become Speaker, there existed a high probability that had Malley not left the Progressive Conservative caucus, Huntjens would have become Speaker. Standing Rule 11(8) governs the manner of how a Speaker is elected in New Brunswick. All MLAs save ministers of the Crown and leaders of political parties are automatically entitled to serve as Speaker. In accordance with Standing Rule 11(8)(a), members who do not wish to be considered for election as Speaker must lodge their notice in writing with the Clerk of the Legislative Assembly by 5pm on the day prior to the election of the Speaker. Huntjens withdrew his name approximately half an hour prior to the $5 \mathrm{pm}$ deadline. In subsequent conversations with reporters Huntjens remarked that the decision to not contest the Speakership, thereby handing Malley the office, was his own decision: "I've had no 
pressure from anyone, this was more of less my decision on this and I looked at this situation and I think it was best for everybody”. However, his fellow Tory colleague Cy Leblanc hinted at a greater political strategy by declaring that "[Huntjens] did this for the team." 36

Although the elevation of MLA Michael Malley to the Speakership was highly irregular and captivated the public's attention, there was still willingness between the opposition and government to cooperate in the Assembly pending the outcome of the vote to approve the budget. On Friday April 7, 2006 the House recorded an equality of votes on Motion 28 to implement the government's budgetary policy. Speaker Malley then exercised his casting vote in favour of the motion citing that as the motion was a matter of supply, it was therefore a question of confidence in the government. Malley stated that "questions of confidence are of such importance that an expression of non confidence should clearly be stated by a majority" and voted in favour of the motion to refer the estimates to the Committee of Supply. ${ }^{37}$

Because the government lacked a majority in the Committee of Supply, the Liberal opposition was successful in recommending that 'supply not be granted to Her Majesty’. This created a bizarre circumstance where the Legislative Assembly had to then vote again on the concurrence of the Committee of Supply's recommendation that supply not be granted. As stated, committees are only creations of Legislative Assemblies; their actions alone cannot dictate a want of confidence in a government. Their purpose is to allow for a more relaxed debate to examine issues in further detail. However in this instance, the Committee of Supply was utilized by the opposition to 
demonstrate its numerical superiority in committee. Upon receiving the chairman's recommendation that supply not be granted, a tie vote again occurred. In this instance Speaker Malley sided with nays and rejected the Committee’s report in order "to maintain the status quo and to allow for further debate.”38

Malley then issued a Speaker's ruling to clarify the procedural ambiguity that had arisen:

Honourable members, it should be stated and made very clear that the motion moved earlier in Committee of Supply that supply be granted to Her Majesty was a procedural formality, a purely symbolic motion that is traditionally moved following the passing of the budget vote in the House. The motion is traditionally decided without dissent following the passing of the budget vote, which occurred earlier today. ${ }^{39}$

Malley then explained that in accordance with various Standing Rules respecting financial matters that supply shall still be deemed granted to Her Majesty.

Prior to Malley’s rejoining of the Progressive Conservative caucus, his conduct as presiding officer was marked by a series of practices, which can be described as unusual but benign. Hansard notes several instances of members of both political parties attempting to inform or correct Speaker Malley on his parliamentary procedure and practice. Because Standing Rule 13 prohibits challenging the Speaker’s conduct during general debate, the comments by Malley's peers are offered in explanatory fashion. Despite the public interest generated by Malley’s Speakership, at this time there existed 
little criticism from the Liberal opposition demanding the resignation of Malley from the Office of Speaker.

\subsection{Speaker Malley's Return to the Progressive Conservatives}

On April 13 ${ }^{\text {th }}, 2006$ Speaker Malley issued a virtually unprecedented statement that served as the principle catalyst in casting doubts respecting Malley’s impartiality as Speaker:

Following a period of reflection, I have decided that it is in the best interest of my constituents that I return to the government caucus. Late this morning, I had a meeting with the Premier, where I informed him that I would be returning to the government caucus effective immediately. The Premier has informed me that he and the members of government caucus agree and welcome me back. I want to sincerely thank the Premier and my colleagues. Although I am now a member of the government caucus, while the House is in session, I do not intend to participate in caucus meetings. With respect to my responsibilities as Speaker of this House, there is no change. I will continue to fulfill the duties of the Office of Speaker in a fair and impartial manner. ${ }^{40}$

The political fallout of Malley’s decision to rejoin the Progressive Conservative caucus was twofold. First, it demonstrably weakened the government's creditability. Only a month prior, Premier Lord effectively dismissed any possibility of Malley rejoining the Progressive Conservative caucus. Second, this about-face provided the 
Liberal opposition an opportunity to break with the previously agreed upon pairing arrangement, which facilitated the government's passage of legislation and budgetary measures in committees.

Political scholar C.E.S. Franks gave his pronouncement of Speaker Malley’s floor crossing, implying that it had heightened the contentious nature of the political climate in New Brunswick. Franks notes that the current debate between the government and opposition consists of matters over "the principles of parliament government", rather than the Assembly contesting issues of substantive policy. ${ }^{41}$ Franks succinctly summarizes that the opposition's concern towards Speaker Malley is that having been elected Speaker as an Independent MLA, he was offered "inducements and joined the government party caucus. ${ }^{2}$ The opposition contends that this switch of party allegiance was improper and can be construed as a reasonable suggestion of bias towards Speaker Malley. Franks compares Malley’s actions to a colloquial metaphor of a “hockey referee announcing during a game that he now supports one of the teams and will join them in the locker room between periods. He can claim that he will continue to be impartial while the game is being played, but trust and credibility have been damaged.”43

The New Brunswick Telegraph Journal was swift to criticize both the Lord government and Malley dubbing the entire incident as 'Tankerpooloza. ${ }^{44}$ Its editorial staff published a summarized list alleged egregious conduct by Speaker Malley. The newspaper specifically criticized Malley for being "in defiance of the tradition that Speakers keep a low political profile” by declaring to Miramichi media that he was responsible for the implementation of key budgetary policies to benefit the Miramichi 
region. $^{45}$

On May $30^{\text {th }}$, the House debated Motion 66, a substantive motion of censure of Speaker Malley’s conduct. Specifically the motion, introduced by Liberal MLA Kelly Lamrock, declared:

WHEREAS circumstances have changed since the election of the Member for Miramichi Bay-du-Vin as Speaker of the Legislative Assembly, and WHEREAS some of these circumstances; specifically, the seeking of one party's approval of admission to caucus, the private negotiation of government benefits in exchange for support, and the Speaker's participation in government announcements of projects which are, or have been represented as being, in exchange for the Speaker's support, would create reasonable doubts in the impartiality of the Office of Speaker, and WHEREAS it is appropriate that this Assembly be given an opportunity to affirm or withhold its support for the Speaker; BE IT RESOLVED that this Legislative Assembly express its lack of confidence in the Speaker. ${ }^{46}$

In speaking with the media, Lamrock elaborated on his motion saying that: "We have seen a Speaker who has asked to be readmitted to the Tory caucus, after serving as an Independent MLA for weeks. During this time, the Speaker negotiated government benefits (for his riding) in exchange for his support and participated in government funding announcements.",47

Formal motions of censure against Speakers are rare in Canada. The only instance of a Speaker being successfully removed from office via a substantive vote occurred in 1875 in Nova Scotia. The Nova Scotia House of Assembly adopted a resolution demanding that Speaker Dickie resign. Of interest was that the resolution noted that his 
conduct in office demonstrated that he did not have the 'requisite qualifications to satisfactorily discharge' the duties of the Office of Speaker. Upon passage of the House's resolution, Speaker Dickie resigned, and another Speaker was promptly elected. ${ }^{48}$

Perhaps the most unexpected example of Speaker Malley’s conduct occurred during the routine proceedings prior to the commencement of debate on Motion 66. From the Speaker's chair, Malley commented:

As the member for Miramichi-Bay du Vin, I will say that today is another great day for Miramichiers, as the $\$ 25$-million fund is working its wonders there. Today, I am proud to announce 100 jobs and to welcome Boston Pizza to the Miramichi. I had attended the opening for the dignitaries, and today, it is opening for the public. Today, with Wal-Mart, Staples, Bulk Barn, EB Games, and Payless, our Power Centre is full-fledged. I want to thank the many people of the Miramichi for making it happen by standing together and the government for making it possible. ${ }^{49}$

Lamrock led debate on Malley's motion of censure arguing that Malley’s action of rejoining the Progressive Conservative caucus made him more beholden to the Premier. He further criticized Malley for lacking neutrality and a failure to understand the Speaker's role:

You have said today, from the chair- today of all days—-that you would stand in that chair, where no one can respond or attack you, and use it to make a statement promoting your own political work and your own political party. It shows that you do not understand or respect the oath you have taken. I am sorry to say those words. I believe you have many strengths. I believe that the success of your political career, in many ways, has been a testament to hard work, but you cannot let temptation and pride lead you to accept a salary when you will not accept the limitations. You cannot use that chair that way. ${ }^{50}$ 
Government House Leader Bev Harrison introduced the government’s counter argument explaining:

This House should concern itself only with the impartiality of the Office of Speaker within the confines of parliamentary precincts, and that the House should find no fault in your promoting the interest of your constituents when, in fact, that becomes part of a partisan role that has become accepted in many jurisdictions. ${ }^{51}$

Harrison described Malley's conduct along the basis of 'situational impartiality' noting that as Speaker, he is required to "wear multiple hats": those of an MLA; a Speaker; and a member of a political party. ${ }^{52}$ Harrison appreciated the political circumstances in New Brunswick are not favourable to independent MLAs, indicating that while he was Speaker it would have been "foolhardy to expect to be re-elected as an independent MLA” and that "political pragmatism must reign”. 53

The motion of censure was defeated by a vote of 27 to 25 allowing Malley to remain as presiding officer for the duration of the Legislative Assembly. ${ }^{54}$ Yet Malley’s tenure as Speaker was short-lived as during summer adjournment Progressive Conservative MLA Peter Measheau announced his resignation prompting Premier Lord to advise Lieutenant Governor Herménégilde Chiasson to dissolve the Legislative Assembly, and call for a general election. In the ensuing election, the Lord government was narrowly defeated. Moreover, the citizens of Miramichi Bay de Vin conducted their 
own plebiscite on Michael Malley; they elected Liberal candidate Bill Fraser with 59\% of the popular vote. ${ }^{55}$ Former Speaker Harrison was re-elected to the riding of HamptonKings and returned to the 56th Legislative Assembly as the Opposition House Leader.

${ }^{30}$ C. E. S. Franks, "Deadlock and the parliamentary tradition; The workings of the legislature should both permit the government to get its business through and allow the opposition to examine and criticize the government's proposals." New Brunswick Telegraph-Journal 6 May 2006, sec. Opinion: A9, .

${ }^{31}$ Elections New Brunswick. Unofficial Provincial By-Election Results. (Online). Fredericton. Communications New Brunswick. November 14 2005. Available:

http://www.electionsnb.ca/03prov/05nov14/05nov14provbyresults-e.asp [Accessed 30 May 2008].

${ }^{32}$ New Brunswick byelection gets federal attention, 31 Oct 2005 2005, CTV.ca, July 222008 $<$ http://www.ctv.ca/servlet/ArticleNews/story/CTVNews/20051029/nb_byelection_051029?s_name=\&no_ ads $=>$.

${ }^{33}$ 'I will no longer be taken for granted,' Malley writes, 20 Feb 2006 cbc.ca/nb, Aug 102008 <http://www.cbc.ca/canada/new-brunswick/story/2006/02/20/nb_malleyletter20060220.html>.

${ }^{34}$ N.B. Premier downplays loss of majority in legislature, 18 Feb 2006, cbc.ca/nb 2 Aug 2008 <http://www.cbc.ca/story/canada/national/2006/02/18/new-brunswick-Premier-060218.html>. 
${ }^{35}$ N.B. Premier downplays loss of majority in legislature

${ }^{36}$ Shannon Hagerman, "Malley 'humbled' as he takes on Speaker's job," New Brunswick Telegraph-Journal 28 Feb 2006 2006, , sec. News.

${ }^{37}$ Malley, Michael [Motion 28 Budget Motion] New Brunswick. Legislative Assembly. Journal of Debates (Hansard)[Unofficial], 55th Assembly, 3rd session, Daily sitting 20, (April 7, 2006), 16

${ }^{38}$ Malley, Michael [Motion 28 Budget Motion], 17

${ }^{39}$ Malley, Michael [Motion 28 Budget Motion], 18

${ }^{40}$ Malley, Michael [Congratulatory Messages] New Brunswick. Legislative Assembly. Journal of Debates (Hansard)[Unofficial], 55th Assembly, 3rd session, Daily sitting 23, (April 13, 2006), 7

${ }^{41}$ Franks, A9

42 "This Speaker must resign," New Brunswick Telegraph-Journal 22 Apr 2006 2006, : A7, .

${ }^{43}$ Franks, A9 
${ }^{44}$ This Speaker must resign, A7

${ }^{45}$ This Speaker must resign, A7

${ }^{46}$ [Recorded Vote-Motion 66 Defeated] New Brunswick. Legislative Assembly. Journal of Debates (Hansard)[Unofficial], 55th Assembly, 3rd session, Daily sitting 40, (May 30, 2006), 27

${ }^{47}$ Stephen Llewellyn, "N.B. Speaker faces non-confidence vote; Liberal MLA says backroom deal- making involving Tanker Malley has weakened respect for legislature," New Brunswick TelegraphJournal 27 Apr 2006 2006, , sec. News: A3

${ }^{48}$ Bourinot, John George, Sir. Flint,Thomas Barnard, Parliamentary procedure and practice in the Dominion of Canada, 3d ed. edited by Thomas Barnard Flint ed. (Toronto: Canada Law Book Co, 1903). 177

${ }^{49}$ Malley, Michael. [Congratulatory Messages] New Brunswick. Legislative Assembly. Journal of Debates (Hansard)[Unofficial], 55th Assembly, 3rd session, Daily sitting 40, (May 30, 2006), 9

${ }^{50}$ Lamrock, Kelly [Recorded Vote-Motion 66 Defeated] New Brunswick. Legislative Assembly. Journal of Debates (Hansard)[Unofficial], 55th Assembly, 3rd session, Daily sitting 40, (May 30, 2006), 27

${ }^{51}$ Harrison, Bev [Recorded Vote-Motion 66 Defeated] New Brunswick. Legislative Assembly. Journal of Debates (Hansard)[Unofficial], 55th Assembly, 3rd session, Daily sitting 40, (May 30, 2006), 34 
${ }^{52}$ Harrison, Bev [Recorded Vote-Motion 66 Defeated] New Brunswick

${ }^{53}$ Harrison, Bev [Recorded Vote-Motion 66 Defeated] New Brunswick, 36

54 [Recorded Vote-Motion 66 Defeated] New Brunswick. Legislative Assembly. Journal of Debates (Hansard)[Unofficial], 55th Assembly, 3rd session, Daily sitting 40, (May 30, 2006), 57

55

Elections New Brunswick. Miramichi Bay de Vin Poll by Poll Results. (Online). Fredericton. Communications New Brunswick. 18 Sept 2006. Available:

http://www.gnb.ca/elections/06prov/06provresultpage-e.asp?PED=11 [Accessed 28 May 2008]. 


\subsection{NEW BRUNSWICK PRECEDENTS OF IMPARTIALITY}

\subsection{Robert McCready: A Similar Incident}

The election of Robert McCready to Office of Speaker in 1978 serves as a precedent for the election of Speaker Malley. McCready's election demonstrates how a close Legislative Assembly can pressure a government to consolidate power. The 1978 New Brunswick general election reduced Richard Hatfield’s Progressive Conservative Party to a two seat majority government where the Progressive Conservatives won 30 seats to the Liberals 28. In order to provide for an increased majority Hatfield, prior to the opening of the Legislature, asked Liberal Robert McCready, the member for Queens South, to become Speaker. This ignited a firestorm of criticism by the Liberal opposition

who felt that they should have been consulted prior to McCready accepting the position. ${ }^{56}$ Consequently, Liberal Leader Joseph Daigle expelled McCready from the Liberal Caucus, thereby making him an independent member of the Legislative Assembly.

It is important to note that the results of 1978 election represented the closest possible outcome at that time for a majority government in New Brunswick. Prior to electoral reform in 1994, the New Brunswick Legislative Assembly had 58 seats. If the general election returned an equality of members from both the government and opposition sides (29 each), this would have resulted in a legislative deadlock in the Assembly. Under this context, the selection of a government member to be Speaker would place the government in a minority position in all circumstances. Because there would never be an equality of deliberative votes, the Speaker would have been unable to 
exercise a casting vote. With this understanding, it would have been imperative for an opposition member, like McCready, to become Speaker in order for the Hatfield government to maintain a working majority. Failure to entice an opposition member to become Speaker would have likely resulted in a political crisis over the failure of the House to select a Speaker. There have been multiple precedents in the Commonwealth pertaining to deadlocked assemblies; most of these Legislatures were short lived as they failed to elect a Speaker, thus requiring the Lieutenant Governor to force dissolution. It is an untended circumstance that the 1994 electoral boundary reforms created the potential for a one seat majority government.

On the opening of the Legislature, Daigle rose before the House to discuss the process that led to the selection of McCready as Speaker. Daigle cited that by not having the Leader of the Opposition second the appointment of the candidate selected as Speaker, it created a disparity from parliamentary tradition in New Brunswick. Consequently he asked that the Legislative Clerk rule Hatfield's motion out of order. Daigle noted that the only opportune time to debate the qualifications of a candidate nominated as Speaker is prior to their appointment. Daigle raised the rhetorical argumentation from Beauchesne’s Parliamentary Rules \& Forms that "the choice of the Speaker is the choice of this House. The House chooses and elects its Speaker; he is in no sense the choice of the government - in no sense the choice of the Prime Minister." ${ }^{\text {} 57}$ Daigle further described practices of the British Parliament with respect to the manner of election of the Speaker.

Hatfield countered Daigle’s arguments stating that in his view he did not believe 
the incident to be a matter of parliamentary procedure in either a British or Canadian context. Additionally Hatfield noted “This is not a case of anyone’s rights being trampled on. I have put forward the name of a person and it has caused a problem of their own making not of mine." 58

Daigle’s main point was that the Liberal Party was prepared to support a candidate who would be unanimously accepted by the House. By forcing a vote on the motion to accept Robert McCready as Speaker, the Liberal Party was indicating that the Premier's actions violated parliamentary customs because the Speaker would be elected on division. ${ }^{59}$ The clerk ruled that Daigle’s objection was not a point of order, thus allowing McCready to become Speaker.

Joseph Daigle was only technically correct in stating that the choice of the Speaker was at that time, a decision of the New Brunswick Legislative Assembly and not the executive branch of government. Both political actors utilized procedural rhetoric to buttress their own partisan advantages. The political undertone was the numerical seat count of the Legislature. Behind Hatfield's rhetoric, allowing McCready as Speaker increased the size of his majority government. By contrast, Daigle arguing against McCready as Speaker would force Hatfield to select another member of the Progressive Conservative caucus, which would decrease the number of Progressive Conservative deliberative votes in the Assembly.

Unlike the actions of Speaker Botsford, where there was direct interference by the executive via Governor Carleton, there had been a transformation of legislative practices 
noted by the establishment of the convention of responsible government. Responsible government created the conditions whereby the executive branch is both drawn from and accountable to the legislative branch of government. Although there is no statutory requirement that members of the New Brunswick Executive Council (Cabinet) be members of the Legislative Assembly, there is the convention in New Brunswick that members of the Executive Council must maintain the confidence of the Legislative Assembly. It is more straightforward for members of the Executive Council to be part of the Legislative Assembly. With the rise of party discipline in New Brunswick, the leader of the political party who can command the support of a majority of seats in the House becomes Premier. This creates a distinction between the de jure executive, the Lieutenant Governor and the de facto executive, the Premier. Since the establishment of responsible government, the choice of Speaker has essentially been the prerogative of the Premier.

With a strict adherence to party discipline, the Premier’s nominee for Speaker is for most circumstances the choice for Speaker. ${ }^{60}$ It is only with the Liberal caucus revolt under Frank McKenna that the selection of Speaker, which shall be discussed in detail below, can be considered a choice that is performed by the House itself. Accordingly Daigle's statements at the time in New Brunswick were incorrect.

The New Brunswick Telegraph Journal notes the strategic political ramifications of McCready’s appointment as Speaker. Few individuals could contest McCready's qualifications as Speaker as he held the position in 1968 as a Liberal. The Telegraph Journal describes the real advantage of having McCready elected as Speaker: it provided 
the Hatfield government with an extra seat in the Legislative Assembly. ${ }^{61}$ Analogous to the situation facing Lord, selecting a non caucus member appointed as Speaker added strategic depth for the Hatfield government in the Legislature. After the election, the Progressive Conservatives had 30 seats, and the Liberals held 28 seats. If Hatfield selected a member of his own caucus as Speaker, the total deliberative seat count would have been reduced to 29-28. ${ }^{62}$ During his tenure as Speaker McCready remained as an independent MLA altering the deliberative seat count to 30 - 27. Upon his resignation as Speaker, McCready officially joined the Progressive Conservative caucus and later become a cabinet minister.

Implicitly, Hatfield's selection of McCready as Speaker confirms the convention of Speaker impartiality. Although McCready was previously a Speaker, he was a Liberal Speaker. He was elected to the 1978 Assembly as a Liberal and was only expelled from the Liberal caucus by leader Robert Daigle. By choosing McCready, Hatfield understood that McCready had the necessary positive qualities required to be Speaker: McCready’s objectivity trumped his political affiliation. If Hatfield doubted that McCready would unnecessarily favour his former Liberal colleagues, he would not have nominated him as Speaker.

Unlike Speaker Malley, McCready did not switch party affiliation while Speaker; he presided as an independent member. Hatfield's two seat majority did not cause the same procedural problems experienced by Lord. The commonality between the two cases is that New Brunswick governments are inclined to utilize the office of Speaker as a means of political leverage to benefit their own circumstances. As documented, it is very 
unlikely that a similar event would occur in Westminster where the independence of the Speaker from partisan involvement is total.

In New Brunswick the partisan affiliation of Speakers does not necessarily comprise their ability to be impartial. New Brunswick Speakers while in office must make concerted efforts to avoid direct bias. Speaker Malley’s principle failure was not his rejoining the Progressive Conservative caucus, any political culpability arising from readmittance rests solely with Progressive Conservative Party Leader Bernard Lord. Malley's most significant fault was directly participating in government announcements while serving as Speaker. This is highlighted by his own statements on the day of his censure, where he thanked the government for providing funding for his riding. Malley's overt statements allowed the Liberal opposition to effectively contextualize the entire 'Malley saga' as a detriment to the Lord government. Malley's public defence in the local newspapers was simply "I'm not considering resigning as Speaker. I won according to the rules, fair and square." ${ }^{63}$ In the public eye, Malley's actions throughout his tenure seemed petty and lacked a degree of self restraint.

Speaker Bev Harrison, in a 2004 Canadian Parliamentary Review roundtable, describes that it is impossible to incorporate the British concept of impartiality within New Brunswick:

Many Speakers have gone out of their way to disassociate themselves from their party. To do that in New Brunswick would not result in anything but the demise of the Speaker. Thus, I have to cleverly decide how I will remain impartial but yet stick to the fact that I was elected as a Progressive Conservative member and that 
I must eventually return to the polls and run a campaign as a Progressive Conservative member. I must always be conscious of that fact. I have a tough enough time explaining to people in the riding who wonder who their representative is now that I am the Speaker. I have to take the time to let them know what I do and how I may do some things better as the Speaker. There are others who take some pride in having the Speaker as their member. In the end, I have to compensate for my inability to speak or address an issue by attending every single function in the riding, from birthdays to anniversaries. As a result, I do not take weekends off because Saturday and Sunday are my two busiest days of the week. I am never at home because I attend all functions. If I were not to attend, I would have no profile, other than to be seen on television sitting in the chair and never giving a speech or casting a vote. Therefore, I have to do those things. ${ }^{64}$

\section{Although the Speaker ranks 4th on the order of precedence within New}

Brunswick, as explained by Harrison, there is a lack of public understanding of the role the Speaker and distinguishing a Speaker’s responsibilities as an MLA with those as presiding officer. Within a close Legislative Assembly, it is imperative that a Speaker remain unbiased and free from governmental influence. The $52^{\text {nd }}$ Legislative Assembly demonstrates the precedent that the New Brunswick Legislative Assembly reached a certain maturity respecting the impartiality of its Speaker.

The incident involving the removal, replacement, and subsequent election of former New Brunswick Speaker Shirley Dysart in 1995 represents a considerable apogee regarding the independence and maturity of the New Brunswick Legislature. Its culmination resulted in the election of New Brunswick Speakers by secret ballot rather than by political appointment. The incident is the closest approximation of a significant debate towards reforming the Office of Speaker in New Brunswick, and encompasses a similar tone of Lord Peel's urge for Speaker impartially in Westminster almost one 
hundred and fifty years prior. In accordance with the Jennings doctrine, this situation satisfies all three aspects for the establishment of a constitutional convention. Although it is only one precedent, as Jennings stated, "A single precedent with a good reason may be enough to establish a rule." ${ }^{, 65}$ 


\subsection{Speaker Dysart: The Precedent for Impartiality}

A Liberal backbench revolt over Liberal Premier Frank McKenna’s removal of Liberal MLA Shirley Dysart as Speaker during a cabinet shuffle was the catalyst for changing how Speakers are selected in New Brunswick. ${ }^{66}$ After the shuffle, McKenna named fellow Liberal MLA Gerald Clavette as Speaker. The Liberal caucus was not pleased with the Premier's arbitrary dismissal of Dysart, and utilized their majority on the multiparty Standing Committee on Procedure to change how the Speaker is chosen. The essence of the committee’s report is now codified under Standing Rule $11 .^{\ddagger}$

While debating the Committee's report, the members of the Legislative Assembly exhibited a rare example of a desire to change the procedural framework of the House for the betterment of the political process than for political self gain. Because it was a government caucus revolt, the policies debated and enacted were saved from substantive

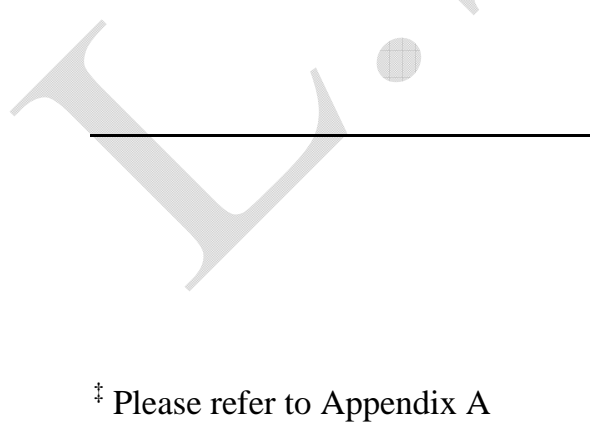


partisan rancour. In effect, the members outlined their own viewpoints on impartiality, and the entire incident transcended typical political circumstances.

In response to the Committee's report Premier McKenna declared that:

I believe we have reached a stage where the public not only demands impartiality and fairness from Speakers, but demands that the institutions be reformed so that the impartiality and fairness can never be brought into question... They want to know that the ultimate arbitrator of decisions in this ... Assembly is beyond political influence. ${ }^{67}$

Lastly McKenna concluded by indicating to the Assembly that the motion would bring an additional element of integrity to the institution of the Speaker for the first time.

Confederation of Regions MLA Brent Taylor remarked in a bipartisan manner the willingness of the Premier to embrace the changes proposed. He thanked Premier McKenna for his "forthrightness to the circumstances which have brought us to this vote today.” In addition, Taylor commended McKenna for his 'political courage' ${ }^{68}$

Progressive Conservative Leader Dennis Cochrane shared the sentiments of his colleagues in stating that:

Undoubtedly, whoever is selected as Speaker today will have some serious decisions to make, and I think that automatically should command our respect. Like past decisions, I am sure that these decisions and future decisions will not be easy, but it will be a little easier knowing that they have the confidence of the House, and that there is a procedure by which a Speaker can be selected, based 
upon the integrity that individual has built up over a number of years with members of the House. I refer to all members of the House in that regard. ${ }^{69}$

After debate, Speaker Clavette put the question before the Legislative Assembly where the motion was passed unanimously. Speaker Clavette then announced that he had two final things to accomplish during his short tenure in office. He thanked the Assembly stating it was a privilege for him to serve as Speaker for four days since the opening of the legislative session. However, he stressed that the duties incumbent upon the Speaker go far beyond simply presiding over debate. Citing his time as Speaker designate, Clavette attended various parliamentary conferences during the adjournment of the House. ${ }^{70}$ Furthermore he recognized that allowing the election of the Speaker of the Legislative Assembly was “a giant step forward by providing for greater openness in the business of this Assembly and greater independence for the role of the Speaker." ${ }^{, 71}$

After these statements, in accordance with section 18 of the Legislative Assembly Act, Speaker Clavette resigned as Speaker to allow for the first occurrence electing a Speaker in the province of New Brunswick by secret ballot. As a result of the subsequent balloting, former Speaker Shirley Dysart was returned to the Office of Speaker.

The quotations of the legislative actors give a direct indication that the practice established during the $52^{\text {nd }}$ Legislative Assembly was more than a straightforward reform of parliamentary procedure; it extended into the realm of parliamentary practice. The politicians stressed that the reform would heighten the impartiality of the Office of Speaker with the implication that the holder of the office would not be directly 
subordinated to the Premier. The justification and support for this premise lies in the statements of Premier McKenna:

In New Brunswick, the traditional way of choosing a Speaker, - and we can put whatever blush we want on it - has essentially been the prerogative of the Premier. This has essentially been used as part of Cabinet making. It has essentially been in that political fashion that the Office of the Speaker has functioned. That is fact. ${ }^{72}$

In the words of Government House Leader Raymond Frenette, "this is a major step towards... the enhancement of the independence of the Speaker in the future.”73

The Speaker, as described by many scholars, is the embodiment of the Legislative Assembly proper. Therefore, the responsibility of ensuring that Speakers are held to this above standard of impartiality is a collective responsibility. Since the change towards an elected Speaker, the Premier no longer has the direct arbitrary prerogative in choosing a Speaker. The most important reinforcement of this principle is understanding rule 11(9) which stipulates that the election of the Speaker is not a question of confidence of the government. This theoretically frees Members to vote for anyone as their ballot is secret. It would be difficult for party whips to enforce discipline on members who vote against the choice of the Premier. Incrementally this would lead to greater independence of the Speaker as the person who would hold the office would be based upon merit and not direct patronage. The Canadian House of Commons is an excellent example of the evolution of the Office of Speaker becoming clearly separated from the machinery of the 
executive branch.

Unfortunately rigid party discipline in New Brunswick has not completely severed the link between the Speaker and the Premier. A Premier, as demonstrated with Lord pressuring his caucus to support Malley as Speaker, continues to have considerable influence over the selection of the Speaker. One of the more powerful measures a Premier can use to force compliance of a 'rogue' Speaker is the power of the purse. In general, the government can 'reward' a specific riding with additional governmental grants and jobs. This in turn creates more political capital which may translate into greater electoral support for the governing party in the next election.

If a Speaker and a Premier belong to the same party but face a disagreement over an issue respecting the Standing Rules or procedure, the Premier will invariably emerge victorious from the argument. Since the Premier is the leader of the political party that the Speaker is associated with, there is a subordination of roles between the two individuals. Often the prospect of reallocating governmental projects to other ridings is enough to ensure a Speaker conforms to the Premier's point of view. If the Speaker is not part of the governing party, or declines to run in the next election, the aforementioned power of the Premier is greatly diminished. In this case, Dysart and Malley represent exceptions to this principle.

The election of Michael Malley as Speaker should have never occurred. Both the Progressive Conservative and Liberal caucuses failed to ensure that the dignity of the Office of Speaker be respected. External political actors who comment that New 
Brunswick Speakers have always represented the independence of the Legislative

Assembly are misguided by nothing more than a romanticised notion of our legislative history.

${ }^{56}$ New Brunswick Telegraph-Journal 10 March 1979, sec. Editorial

${ }^{57}$ Arthur Beauchesne, et al, Rules and forms, with annotations, comments and precedents; a compendium of Canadian parliamentary practice, prepared for the use of members of Parliament, 4th ed. (Toronto: Carswell Co, 1958), 22

${ }^{58}$ Hatfield, Richard "[Appointment of Speaker]." New Brunswick. Legislative Assembly. Synoptic Report. 49th Parliament, 1st Session, Vol. 1 (March 12, 1979), 10

${ }^{59}$ Daigle, Joseph "[Appointment of Speaker]." New Brunswick. Legislative Assembly. Synoptic Report. 49th Parliament, 1st Session, Vol. 1 (March 12, 1979), 10

${ }^{60}$ New Brunswick. Legislative Assembly, "Journal of debates (Hansard) ... of the ... Legislative Assembly of the Province of New Brunswick," Third Session of the 52nd Legislature of the Province of New Brunswick 9 (1994). 3969

${ }^{61}$ New Brunswick Telegraph-Journal 10 March 1979, sec. Editorial

${ }^{62}$ New Brunswick Telegraph-Journal 10 March 1979, sec. Editorial 
${ }^{63}$ Nathan White, "I won't quit Speaker's job, Tanker says; Embattled Speaker to face nonconfidence vote today in legislature," New Brunswick Telegraph-Journal 30 May 2006, sec. News: A1/A9

${ }^{64}$ Ken Kowalski, et al, "The impartiality of the speakership: A round table," Canadian Parliamentary Review 27.2 (2004) $<$ http://proquest.umi.com/pqdweb?did=668833661\&Fmt=7\&clientId=65345\&RQT=309\&VName=PQD $>$.

${ }^{65}$ Jennings, Parliament, 70

${ }^{66}$ Shannon Hagerman, "Former Speaker says he would step aside to help end gridlock; But Bev Harrison says the Tory caucus won't put any pressure on Tanker Malley to resign," New Brunswick Telegraph-Journal 25 May 2006 2006, , sec. News: A1/A8, .

${ }^{67}$ McKenna, Frank “[Debate on Motion 110]." In New Brunswick. Legislative Assembly. Journal of Debates (Hansard). 52nd Legislature 3rd Session, Vol. 9 (December 2, 1994), 3969

${ }^{68}$ Taylor, Brent “[Debate on Motion 110]." New Brunswick. Legislative Assembly. Journal of Debates (Hansard). 52nd Legislature 3rd Session, Vol. 9 (December 2, 1994), 3970 
${ }^{69}$ Cochrane, Dennis “[Debate on Motion 110]." New Brunswick. Legislative Assembly. Journal of Debates (Hansard). 52nd Legislature 3rd Session, Vol. 9 (December 2, 1994), 3972

${ }^{70}$ Clavette, Gerald “[Debate on Motion 110]." New Brunswick. Legislative Assembly. Journal of Debates (Hansard). 52nd Legislature 3rd Session, Vol. 9 (December 2, 1994), 3978

${ }^{71}$ Clavette, Gerald “[Debate on Motion 110]."

${ }^{72}$ McKenna, Frank “[Debate on Motion 110]." New Brunswick. Legislative Assembly. Journal of Debates (Hansard). 52nd Legislature 3rd Session, Vol. 9 (December 2, 1994), 3969

${ }^{73}$ Frenette, Raymond “[Debate on Motion 110]." New Brunswick. Legislative Assembly. Journal of Debates (Hansard). 52nd Legislature 3rd Session, Vol. 9 (December 2, 1994), 3976 


\subsection{THE CASTING VOTE}

\subsection{Parliamentary Practice}

As a MLA, the Speaker is entitled to vote; however, Standing Rule 14 restricts Speakers to exercise their vote only when there is a tie. By nature, voting is political and thus is at odds with a Speaker being impartial. Therefore, there are parliamentary conventions that guide the Speaker when voting to avoid accusations of bias. In the $55^{\text {th }}$ Legislative Assembly, Speakers were required to cast multiple votes due to the virtual tie between government and opposition members. The frequent occurrence of casting votes caused the opposition to claim that New Brunswick Speakers deviated from parliamentary practice. An examination of Speaker Harrison's voting practices will serve as a case study. When analyzed, Harrison's voting indicates favouritism towards the government.

May’s notes several precedents that serve as guidance for Commonwealth parliamentary assemblies in determining how the Speaker should exercise their casting vote. Specifically May’s cites that in order to avoid impugning a Speaker's motives, Speakers should exercise their casting vote in a manner to not make the decision of the House final. ${ }^{74}$ In brief May's explains that there are three principles governing the Speaker's casting vote:

1. That the Speaker should always vote for further discussion, where this is possible

2. that where no further discussion is possible, no decisions should be taken except by a majority

3. That a casting vote on an amendment to a bill should leave the bill in its existing form. ${ }^{75}$ 
With respect to the $55^{\text {th }}$ Legislative Assembly, the practices of the Speaker's casting vote conformed to the second and third conventions listed in May's. However, there was a stark departure in adherence to the principle that the Speaker should always vote for further discussion. The incidents establishing the this convention occurred in 1796 by British Speaker Addington. On the third reading of the Succession Duty on Real Estates Act where the motion provided that the bill be read a third time the subsequent day Speaker Addington exercised his casting vote with the yeas explaining that the Speaker should vote for further discussion. ${ }^{76}$

On 1 May 1828, British Speaker Manners-Sutton was required to exercise his casting vote on whether a bill should be read a second time. He acknowledged that the bill had been discussed by the House, the absence of a majority decision meant that the House as a body was undecided as how to proceed. Manners-Sutton held that to properly exercise his duties as Speaker that the bill should be read a second time to allow for further consideration. ${ }^{77}$

On December $14^{\text {th }}$, 2005 Speaker Harrison exercised his casting vote and defeated on second reading a private members public bill introduced by the Liberal opposition. Criticism was raised by Opposition Leader Shawn Graham as to the apparent departure from practices described in procedural manuals referenced by New Brunswick. In specific, Graham cited the practices of the Canadian House of Commons by referring to a recent decision by Speaker Peter Milliken in exercising a casting vote on second reading 
of a private members public bill.

Bill C-215, an act to amend the Criminal Code (consecutive sentence for use of firearm in commission of offence), was introduced by Conservative Member of Parliament Daryl Kramp. Prior to exercising his vote, Milliken issued a brief statement that "As is the practice, I am voting for further debate on this bill" and thus referred the legislation to the committee Standing Committee on Justice, Human Rights, Public Safety and Emergency Preparedness. ${ }^{78}$ Graham concluded his remarks by comparing the incongruent New Brunswick practice with other Commonwealth jurisdictions, raising the direct question of "Why are we breaking that [continuance of a bill at second reading] tradition?,79

In an interjection, Government House Leader Brad Green countered Graham’s assertions citing that his raising of the question was indirectly challenging the authority of the Speaker, which is in violation of the Standing Rules of the Legislative Assembly. Green explained that there were precedents for the defeating of a bill at second reading, citing that the same bill was defeated in the previous legislative session. ${ }^{80}$ In addition, Green criticized Graham: "It is not enough to say that by voting in favour, there is merely a vote to continue debate at another level. It is a decision of this House saying whether we support a bill in principle or whether we do not." ${ }^{\text {"1 }}$

Speaker Harrison concluded the matter by indicating that although the Speaker can examine the practices of other parliamentary assemblies, the exercising of a casting vote is inherently discretionary in nature, and that it is not a ruling. Harrison indicated 
that in the absence of any regulation or practice in New Brunswick, presiding officers are free to establish their own practices:

I do think that, in looking at what we do have on the issue, it is somewhat vague to the extent that, in cases not provided for, these Standing Rules questions shall be decided by the Speaker or Chairman, whose decisions may be based . . . It leaves a lot of latitude here. Because I do not regard this as a ruling, I regard it as a casting vote, therefore, it was a decision of the Speaker to do that. ${ }^{82}$

Seven days later on December 21, 2005, Speaker Harrison voted in favour of a government bill facing second reading. Harrison denotes the distinction between voting for an opposition and government bill by remarking “The motion and bill are part of government policy and part of its direction, as indicated to the people of New Brunswick.”83 Opposition Leader Graham noted the immediate discrepancy between defeating the private members public bill and allowing the government bill. Harrison's response was a reiteration that the legislation was clearly a matter of governmental policy, and therefore warranted second reading. ${ }^{84}$

The practice established by Speaker Harrison of negating private members public legislation at second reading continued under Speaker Malley. However, beyond the simple declaration of indicating his voting intentions Malley did not offer any further explanation when asked by Liberal MLA Peter Allaby for his rationale behind defeating a tied opposition sponsored motion. ${ }^{85}$ 


\subsection{Precedents and Commentary}

The practices of the Australian State Assemblies are similar to the province of New Brunswick: all demonstrably depart from the Westminster ideal. To quote former House of Commons Speaker Phillip Laundry, Australian Speakers do not reflect the traditions of Westminster where the British jurisdiction is to be used as a 'yardstick.' Instead "they reflect the robustness of Australian political life. They serve in a tough arena in which there is no place for those who bruise easily." ${ }^{86}$

Former New South Wales Speaker, John Murray, comments on the Australian practices respecting casting votes noting that the small numerical size of colonial parliaments elevated the level of partisanship and the importance of an individual member's vote:

Furthermore, it is also argued that the smaller number of members in colonial parliaments and fluctuating allegiances meant that a governing party's majority could be short lived. Thus the political allegiance of the Chair became important when there was a tie in votes and they were to exercise a casting vote. The first casting vote in the Legislative Assembly of New South Wales was given on 12 August 1856 by the first Speaker, Sir Daniel Cooper, who before voting said "As I can find no precedent to guide me, I must use my own judgment." Interestingly enough this first casting vote was against the Government with Speaker Cooper voting against the Government members on a motion for the adjournment of the debate upon a private member's motion. ${ }^{87}$

Canadian House of Commons Speaker James Jerome, although never exercised a casting vote, indicated what his hypothetical response would be if faced with such a 
dilemma; Jerome adheres to the three conventions outlined by May’s:

In exercising the casting vote the Speaker is guided by certain precedents. He is not expected to give weight to his own personal inclination but rather to use his casting vote in such a way as to keep the matter before the House open for further consideration wherever possible. I have always been fascinated by the obvious corollary of the proposition, namely that if a measure if before the House for a final vote at third reading, with no opportunity for further amendment or discussion, and the votes for and against are equal, the Speaker should use his casting vote to reject the measure. The principle here is that the Speaker should not by his casting vote sanction a change in the law but should opt for the status quo. On the other hand it has been argued that the Speaker should not by his casting vote make himself responsible for the rejection of a government measure. $^{88}$

On 29 March, 2004 a casting vote occurred in the Saskatchewan Legislative Assembly. NDP Speaker Myron Kowalsky utilized his casting vote on the Address in Reply to the Speech from the Throne, thereby upholding confidence in Lorne Calvert's 2 seat majority government. Unlike in New Brunswick, Kowalsky’s casting vote prompted little controversy from either the opposition Saskatchewan Party or members of the media.

Of significance is that Deputy Premier Clay Serby was absent from the Legislative Assembly for an extended period of time due to cancer treatment. ${ }^{89}$ Therefore with an NDP Speaker and Serby's absence, only 28 NDP members could vote, which placed the government in a virtual tie with the opposition Saskatchewan Party. Similar to the Lord government, the Saskatchewan government faced potential procedural problems within the Committee of the Whole House and Supply, where the opposition would 
outnumber the government members.

The political circumstances in Saskatchewan were considerably different than New Brunswick: the equality of votes was a consequence of a member undergoing health treatment. This salient fact meant that it was politically unacceptable for the opposition to callously exploit any perceived procedural leverage they had within a tied Legislative Assembly. Opposition Leader Brad Wall indicated that his party would not try to cause a defeat of the government on the budget. ${ }^{90}$ In this light, Speaker Kowalsky only exercised one casting vote until the return of Serby to the Legislative Assembly.

The Address in Reply to the Speech from the Throne provides a Legislative Assembly an opportunity to debate the agenda of the government as presented by the Lieutenant Governor. Historically, parliaments tended to restrict debate to the priorities of the government, and draft a comprehensive response to each specific governmental priority. A modern Address in Reply provides the legislative body the opportunity to discuss any issue affecting members. ${ }^{91}$ An Address in Reply is a question of confidence in the government. If an Address in Reply rejects the government's agenda outright, convention necessitates the government to resign and ask the Lieutenant Governor for a dissolution of the Legislative Assembly. Speaker Kowalsky motivated his decision to vote in favour of the motion with the following statement:

In general the principle that applies in this instance is that decisions of the legislature should be taken only by a majority. In a vote such as this one, that is a test of the Assembly's confidence in the government, the decision of nonconfidence should be clearly stated by a majority. It would not be appropriate for 
the vote of the Speaker alone to overturn the status quo as determined in the last election. $^{92}$

The only modern prior incident of a New Brunswick presiding officer exercising their casting vote occurred on 17 June, 1980 during Hatfield’s two seat majority government. During the previous legislative sitting, Speaker McCready expressed concern that the Liberal introduced Bill 56, an Act to amend the Electric Power Act, may infringe Standing Rule 76(3), and he deferred second reading to June 17 to determine if Bill 56 was in order. ${ }^{93}$

On 17 June, McCready was absent from the Legislative Assembly, and unable to provide his ruling on Bill 56. Normally, McCready’s absence would not be problematic as the Deputy Speaker fulfills his role; however, Premier Hatfield and an additional Tory MLA were absent from the Assembly, thus reducing the total number of government MLAs to 28. With the Deputy Speaker in the chair, the total deliberative votes were 27 for both the Liberals and the Progressive Conservatives. This unique situation meant that the Liberals could influence the outcome of the June $17^{\text {th }}$ sitting.

During Question Period, the Liberals demonstrated the partisan tone of the sitting by boasting of their numerical superiority in the Legislature due to the temporary absence of Progressive Conservative MLA James Tucker, which further reduced the Conservative ranks to 26. Accordingly, the Liberals were able to reverse the Deputy Speaker's decision declaring that the House must wait for Speaker McCready's ruling on the admissibility of 
Bill 56 before the Deputy Speaker would consider the bill for second reading. Because of the opposition's temporary strength in the House, this started a protracted, heated exchange between opposition and government members resulting in the deputy Speaker frequently intervening in debate, and declaring several recesses in an effort to reduce the deteriorating partisan exchanges. Immediately after the Liberals successfully allowed the debate on the motion to read Bill 56 'forthwith', Conservative cabinet minister Gerald Merrithew introduced an amendment to 'six month hoist' the bill. This also had the latent effect of delaying the recorded vote on Bill 56 to later in the afternoon when absent Progressive Conservative MLA James Tucker arrived in the chamber. When debate on the amendment expired, the Deputy Speaker put the question before the House resulting in an equality of votes: 27 for and 27 against. He then issued the following casting vote:

It is most important to preserve the impartiality and, unfortunately, the neutrality of the Chair. In the act of casting a vote, the neutrality itself - which is why I am smiling - is actually voided and voided very quickly; therefore, it is incumbent upon the presiding officer to cast a vote in such a manner as to preserve uppermost the impartiality of the Chair. It is also incumbent upon the presiding officer of the Assembly, in casting that vote, to maintain order, to maintain decorum and to advance the debate and provide an opportunity for further discussion. Bearing those duties and responsibilities in mind on this particular occasion, and have rendered throughout this day's sitting, I find that perhaps the best interest of this Assembly can be served and the impartiality of the Chair can be preserved in my casting a vote in favour of the amendment. ${ }^{94}$

The deputy Speaker then performed a second casting vote on the amended motion by voting in favour of postponing second reading of Bill 56 for six months. Due the prorogation of the Legislative Assembly, the Bill died on the order paper. 


\subsection{Analysis}

In light of these recent precedents elsewhere in the Canadian realm of parliamentary practice, the actions of Speaker Harrison represented a departure from traditional practices pertaining to the Speaker's casting vote. An effectively tied House represents the Speakers 'worst nightmare’ as it forces the Speaker into a position whereby exercising multiple casting vote places him in a potentially political position. The historical precedents relating to the casting vote developed throughout the Commonwealth for the purposeful reason of avoiding situations where Speakers may be considered partial.

Speaker Harrison's conduct during the $55^{\text {th }}$ Legislative Assembly demonstrated favouritism towards the governing Progressive Conservatives. The rhetorical argument that Speaker Harrison was merely anticipating that a motion introduced by the opposition would be defeated on third reading is incorrect. To defeat opposition motions for the sake of legislative expediency is improper. It is not the role of the Speaker to anticipate the outcome of debate in the House. 
Although the current system of rigid party discipline in New Brunswick makes the results of votes predictable, it does not imply that this is always the case. A MLA expressing dissatisfaction, and voting contrary to the wishes of his party at third reading could alter the majority will of the Legislative Assembly. This scenario is not improbable given Michael Malley’s circumstances. The misuse of the casting vote by Speaker Harrison is a more egregious error by a Speaker than the impartiality of Speaker Malley. Granted Malley’s conduct was more sensational; there is a more latent problem with Harrison's use of the casting vote. There is the potential for procedural scholars to scour the New Brunswick Legislative Assembly’s Hansard and inappropriately cite Harrison's negation of private members motions on second reading as a proper source of precedent.

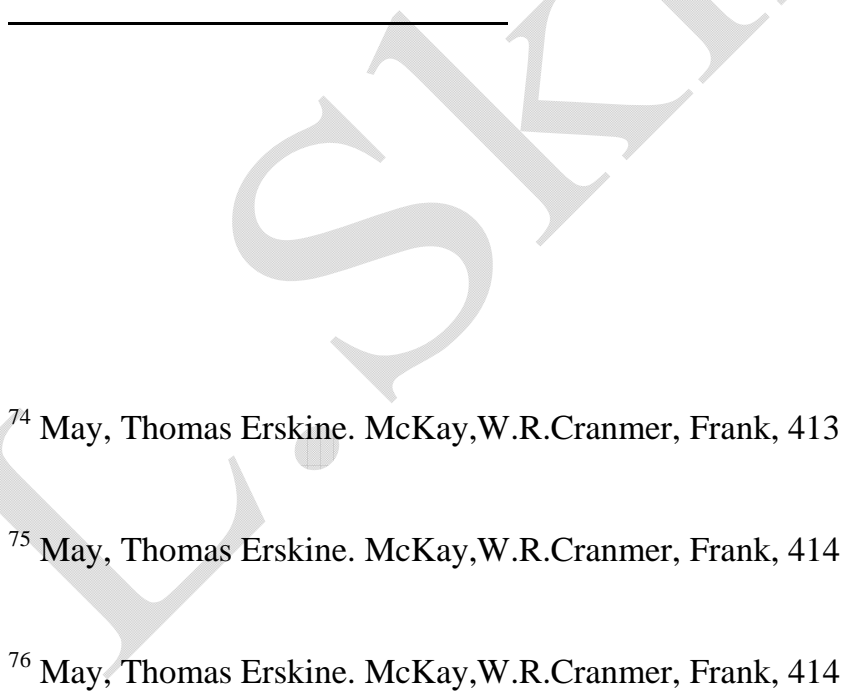


${ }^{77}$ May, Thomas Erskine. McKay,W.R.Cranmer, Frank, 415

${ }^{78}$ Canada. Parliament. House of Commons. Debates, 38th Parliament, 1st Session, vol. 91, May 4, 2005. (Online). Available:

http://www2.parl.gc.ca/HousePublications/Publication.aspx?Language=E\&Pub=Hansard\&Mode=1\&Parl= 38\&Ses=1\&Doc=91\#Int-1260055 [Accessed July 30, 2008]

${ }^{79}$ Graham, Shawn [Recorded Vote-Second Reading of Bill 23 Defeated] New Brunswick.

Legislative Assembly. Journal of Debates (Hansard)[Unofficial], 55th Assembly, 3rd session, Daily sitting 6, (December 14, 2005)., 35

${ }^{80}$ Green, Brad [Recorded Vote-Second Reading of Bill 23 Defeated] New Brunswick.

Legislative Assembly. Journal of Debates (Hansard)[Unofficial], 55th Assembly, 3rd session, Daily sitting 6, (December 14, 2005), 36

${ }^{81}$ Green, Brad [Recorded Vote-Second Reading of Bill 23 Defeated] 
${ }^{82}$ Harrison, Bev [Recorded Vote—Second Reading of Bill 23 Defeated] New Brunswick.

Legislative Assembly. Journal of Debates (Hansard)[Unofficial], 55th Assembly, 3rd session, Daily sitting 6, (December 14, 2005), 37

${ }^{83}$ Harrison, Bev [Recorded Vote—Motion for Second Reading of Bill 25 Carried] New Brunswick. Legislative Assembly. Journal of Debates (Hansard)[Unofficial], 55th Assembly, 3rd session, Daily sitting 10, (December 21, 2005),.54

${ }^{84}$ Graham, Shawn [Recorded Vote—Motion for Second Reading of Bill 25 Carried] New Brunswick. Legislative Assembly. Journal of Debates (Hansard)[Unofficial], 55th Assembly, 3rd session, Daily sitting 10, (December 21, 2005), 54

${ }^{85}$ Allaby, Peter [Recorded Vote—Second Reading of Bill 59 Defeated] New Brunswick. Legislative Assembly. Journal of Debates (Hansard)[Unofficial], 55th Assembly, 3rd session, Daily sitting 29, (May 3, 2006), 57

${ }^{86}$ Laundy, 156 
${ }^{87}$ John Murray, The Role of the Speaker and Political Reality - paper presented by the Hon. John Murray MP, Speaker of the Legislative Assembly of New South Wales (Brisbane, Queensland, Australia: Australia and New Zealand Association of Clerks-at-the-Table, 2002), . www.anzacatt.org.au. 5 July 2008 <http://www.anzacatt.org.au/prod/anzacatt/anzacatt.nsf/ca3cb73640e4b7d4ca2567ee0016638b/56e7a77ded c3a67dca256d18001dd041!OpenDocument>.\}

${ }^{88}$ Laundy, 121

${ }^{89}$ Wood, James " NDP survives budget vote " [Saskatoon] The Star Phoenix 25 April 102006 , sec. News: A1/A8

${ }^{90}$ Wood, " NDP survives budget vote "

${ }^{91}$ Arthur Beauchesne, et al, Beauchesne's Rules \& forms of the House of Commons of Canada : with annotations, comments, and precedents, 6th ed. / by Alistair Fraser, W.F. Dawson, John A. Holtby ed. (Toronto, Ont: Carswell, 1989) ,82 
${ }^{92}$ Kowalsky, Myron [Address in Reply to the Speech from the Throne] Saskatchewan. Legislative Assembly. Debates and Proceedings (Hansard), 25th Assembly, vol 47 1st session, Daily sitting 8 (March 29th, 2004), pp. 235-36

${ }^{93}$ McCready, Robert “[Speaker’s Ruling on Bill 56]” New Brunswick. Legislative Assembly. Journal of Debates (Hansard) 49th Assembly, 2nd session, Daily sitting 54, (June 17, 1980), 4576

${ }^{94}$ Deputy Speaker “[Deputy Speaker’s Casting Vote on Bill 56]” New Brunswick. Legislative Assembly. Journal of Debates (Hansard) 49th Assembly, 2nd session, Daily sitting 54, (June 17, 1980), 4576 


\subsection{CONCLUSION}

\subsection{Is True Impartiality Possible?}

The New Brunswick Political Processes Financing Act serves as an impediment towards allowing 'safe passage’ of the Speaker in a subsequent general election. Established in 1978, the Political Processes Financing Act provides registered political parties with public monies using a mathematical calculation based on the number of votes they garnered in the previous general election. If under the current parameters of the statute, the major political parties agreed to not contest an incumbent Speaker, they would be purposefully limiting the total amount of public monies they could earn for each general election. Unless the Speaker elects to run as an independent, there would be a weighed favouring towards the Speaker's political party to the direct disadvantage of other parties. In terms of organized political machinery in New Brunswick, political parties do not have the same amount of material wealth when compared to their federal counterparts. Therefore, not contesting a Speaker's riding under the current rules would be unthinkable from a partisan perspective.

Many smaller Commonwealth jurisdictions in the Caribbean decided to have their Speakers appointed from outside the political sphere to ensure impartially. Since the presiding officer would not face the rigors of an election nor belong to a political party, most allegations of bias or favouritism would cease. Numerically speaking, smaller Legislative Assemblies have an increased preponderance for the Office of Speaker to be politicized due to the relative value of a single vote being intensified. For the House of 
Commons in London, where there are 646 members, the decision to not contest the Speaker's seat is relatively inconsequential as the mathematically probability creating a situation of continual tie votes is minimal. By contrast the Legislative Assembly of the Cayman Islands is comprised of 15 seats. Currently the government of the Cayman Islands is undergoing constitutional reform where there is a proposal to have an appointed Speaker. The discussion surrounding this initiative is a direct consequence of the recent implementation of political parties in the Cayman Islands' Legislative Assembly. ${ }^{95}$ Because the New Brunswick Legislative Assembly only has 55 seats it can be classified as a smaller Assembly.

Substantive legislative reform such as the above would be considerably difficult in New Brunswick. Many of the more drastic recommendations outline by the New Brunswick’s 2005 Commission on Legislative Democracy were not implemented in the government's 2007 response. Although the commission did not recommend an appointed Speaker, a change of this nature would be significant and incongruent with the legislative tradition of New Brunswick.

\subsection{Partisanship Reigns}

Ultimately, New Brunswick Speakers are creations of the New Brunswick Legislative Assembly. Insofar as Speakers remain elected MLAs, they cannot divorce themselves from politics. To bind New Brunswick Speakers to the impartiality standard of Westminster without a rational consideration of why the rule in Westminster was 
established creates a paradoxical circumstance. The New Brunswick political actors recognize the procedural existence of a certain manner of conduct without appreciating the higher rational of why the rule should exist.

Lord Peel's statement that "I do not think it for the public advantage that the election for the Chair should necessarily be made the object of a party,” simultaneously denotes the reason why the convention exists and the principle impediment towards its implementation: its enforcement rests with the entire Legislative Assembly. ${ }^{96}$ Individual Speakers can certainly place their own style on their Office of Speaker; however, it is the responsibility of the entire legislative body to ensure that the higher normative values behind the convention of Speaker impartiality are upheld. In this manner, the true issue preventing methodical reform is political culture. The vindictive political climate in New Brunswick often means that proposals introduced by one political party are met with suspicion by other parties. Newly formed governments often forget the disproportionate power balance in the Assembly that favours government and utilize the same procedural tools while in power that they denounced in opposition creating a stasis preventing political reform. Unfortunately the Office of Speaker is still vulnerable to political exploitation by the Premier. Politics in New Brunswick remains firmly local where the allocation of government funding can make the difference between electoral victory and defeat. With the brief exception of the debate surrounding Shirley Dysart being elected Speaker by the House instead of being appointed by the Premier, there has been little bipartisan discussion in New Brunswick of what the conduct of the Speaker should be. There is a collective failure of imagination of the Legislative Assembly to perceive 
politics being done another fashion.

For New Brunswick, the absence of minority parliaments creates a political climate that does not readily foster a culture of political cooperation between parties. By contrast, the neighbouring province of Nova Scotia has a strong deliberative Assembly due to a prolonged period of minority governments. ${ }^{\S}$ This has normalized a situation where the Speaker must be satisfactory to opposition members, and gross disregard for opposition concerns would result in the Speaker being removed from office. The office of the New Brunswick Speaker is undergoing a linear progression towards a more impartial entity. It is doubtful that New Brunswick will reach the benchmark of Westminster impartiality because the Speaker’s riding is contested by political parties. Consequentially, this necessitates New Brunswick Speakers belonging to political parties if they wish have a realistic chance in being re-elected to the next Legislature. By belonging to a political party, New Brunswick Speakers are partisan by nature; however,

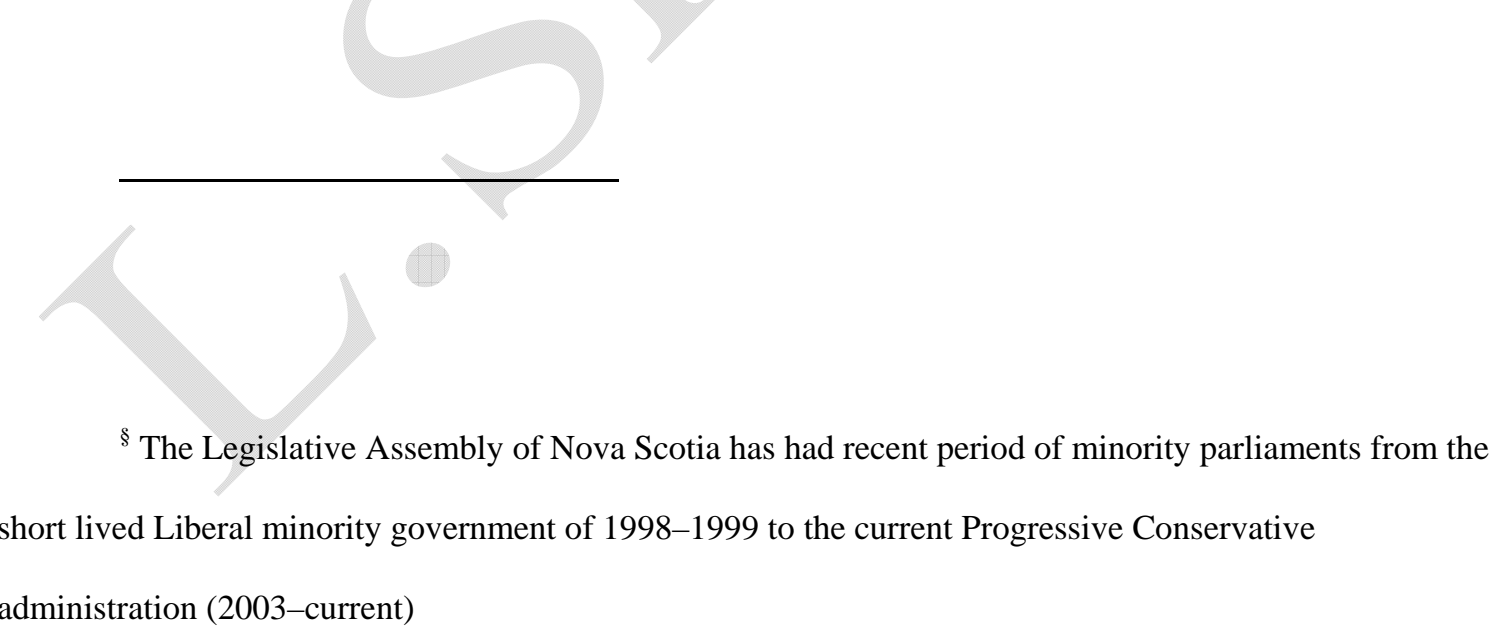


they have a higher normative duty to be impartial. New Brunswick Speakers must strive to balance these two opposing forces.

Accordingly, this begets the question of what standard of impartiality should New Brunswick Speakers ascribe to hold? British historical antecedents only provide a contextual framework for understanding the convention, and should not be used as the sole means of reference since New Brunswick precedents carry more weight. The concurring statements of political party leaders during the Dysart incident provide for the most evident crystallization of convention that the Office of Speaker should be elevated beyond the traditional devices of partisanship. The conduct of the Speaker should not be the subject of debate in the greater public discourse or as McKenna described, "[the public wants] to know that the ultimate arbitrator of decisions in this ... Assembly is beyond political influence." ${ }^{97}$ By creating a situation where the public becomes focused on the Speaker's conduct rather than the debate occurring under the Speaker's watch, the political process becomes dysfunctional. This condition itself is premised on an Assembly being a deliberative rather than ceremonial body. If the level of debate reaches a critical threshold, a Speaker's response to criticism of bias creates further attentions thus creating an intractable morass as experienced by Speaker Malley.

The $55^{\text {th }}$ Legislative Assembly represents a notable example of when the convention of impartiality reaches the flashpoint described above during a deliberative Assembly. The actions of both Speaker Malley, via his overt partisanship, and Speaker Harrison's improper usage of the casting vote are demonstrative of both individuals overstepping the established bounds of the convention within New Brunswick. The $55^{\text {th }}$ 
Assembly represents a regression from the ideals espoused during the Dysart incident. The principal failure is not that the actions occurred; rather, that the Assembly tolerated the deviations from the procedural norms by failing to substantively censure the Speakers for the sake of crass political survival. Seven individuals, comprising both Liberal and Progressive Conservatives, were members of the Assembly during the Dysart incident and the $55^{\text {th }}$ Legislative Assembly. For them to not comment in a capacity as senior statesmen of the province is questionable.* ${ }^{* *}$ The rancorous political realm of New Brunswick does not mirror Westminster. Bernard Lord's one seat majority government clearly illustrates the innate political values of New Brunswick where political pragmatism is favoured over parliamentary convention. As long as there is an extreme antagonistic political culture combined with strict party discipline, the impartiality of the Chair remains discretionary and subordinated to a Premier’s prerogative.

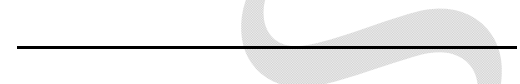

** The seven individuals who were MLAs of both the $52^{\text {nd }}$ and $55^{\text {th }}$ Legislative Assembles are: Dale Graham, Percy Mockler, Eric Allaby, Frank Branch, Stuart Jamieson, Elvy Robichaud, and Larry Kennedy. 
${ }^{95}$ Bothwell, Suzann. "Re: Impartiality of the Speaker." E-mail to the author. 9 June 2008

${ }^{96}$ Jennings, Parliament, 66

${ }^{97}$ McKenna, Frank “[Debate on Motion 110]." New Brunswick. Legislative Assembly. Journal of Debates (Hansard). 52nd Legislature 3rd Session, Vol. 9 (December 2, 1994), 3969 


\section{BIBLIOGRAPHY}

\section{Works Cited}

Bourinot, John George, Sir. Flint, Thomas Barnard. Parliamentary Procedure and Practice in the Dominion of Canada. 3d ed. edited by Thomas Barnard Flint ed. Toronto: Canada Law Book Co, 1903.

Beauchesne, Arthur, et al. Rules and Forms, with Annotations, Comments and Precedents; a Compendium of Canadian Parliamentary Practice, Prepared for the use of Members of Parliament. 4th ed. Toronto: Carswell Co, 1958.

Beauchesne, Arthur, et al. Beauchesne's Rules \& Forms of the House of Commons of Canada: With Annotations, Comments, and Precedents. 6th ed. / by Alistair Fraser, W.F. Dawson, John A. Holtby ed. Toronto, Ont: Carswell, 1989

Bothwell, Suzann. "Re: Impartiality of the Speaker." E-mail to the author. 9 June 2008

CBC News. "'I will no longer be taken for granted,' Malley writes."b.ca/nb. 20 Feb 2006. Canadian Broadcasting Corporation. CBC New Brunswick. Available: <http://www.cbc.ca/canada/newbrunswick/story/2006/02/20/nb_malleyletter20060220.html>. [Accessed Aug 2 2008]

---. "N.B. premier downplays loss of majority in legislature."CBC.CA/NB. 18 Feb 2006.

Canadian Broadcasting Corporation. CBC New Brunswick. (Online)

<http://www.cbc.ca/story/canada/national/2006/02/18/new-brunswick-premier-060218.html>. [Accessed Aug 2 2008] 
Canada. Department of Justice,” Constitution Act, 1867 (Online) Available:

<http://laws.justice.gc.ca/en/Const/c1867_e.html> [Accessed 22 July 2008]

---. Parliament. House of Commons. Debates, 38th Parliament, 1st Session, vol. 91, May 4, 2005.

(Online). Available:

<http://www2.parl.gc.ca/HousePublications/Publication.aspx?Language=E\&Pub=Hansard\&Mode=1\&Parl

=38\&Ses=1\&Doc=91\#Int-1260055 $>$ [Accessed July 30, 2008]

CTV.ca News Staff. "New Brunswick byelection gets federal attention." CTV.ca. 31 Oct 2005

CTVglobemedia Inc. CTV News. (Online). Available:

<http://www.ctv.ca/servlet/ArticleNews/story/CTVNews/20051029/nb_byelection_051029?s_name=\&no_ ads $=>$. [Accessed July 22 2008]

Franks, C. E. S. "Deadlock and the Parliamentary Tradition; the Workings of the Legislature should both Permit the Government to Get its Business through and Allow the Opposition to Examine and Criticize the Government's Proposals." New Brunswick Telegraph-Journal 6 May 2006, sec. Opinion: A9.

Hagerman, Shannon. "Malley 'Humbled' as He Takes on Speaker's Job." New Brunswick Telegraph-Journal 28 Feb 2006, sec. News.

--- "Former Speaker Says He would Step Aside to Help End Gridlock; but Bev Harrison Says the Tory Caucus Won't Put any Pressure on Tanker Malley to Resign." New Brunswick Telegraph-Journal 25 May 2006, sec. News: A1/A8.

Hannay, James. History of New Brunswick. St. John: N.B., J.A. Bowes, 1909.

Heard, Andrew David. Canadian Constitutional Conventions : The Marriage of Law and Politics. Toronto; Oxford: Oxford University Press, 1991.

Jennings, Ivor, Sir. The Law and the Constitution. 5th ed. London: University of London Press, 1959a. 
---. Parliament. 2d ed. Cambridge: University Press, 1957b.

Kowalski, Ken, et al. "The Impartiality of the Speakership: A Round Table." Canadian Parliamentary Review 27.2 (2004): 4.

$<$ http://proquest.umi.com/pqdweb?did=668833661\&Fmt=7\&clientId=65345\&RQT=309\&VName=PQD> .

Laundy, Philip. The Office of Speaker in the Parliaments of the Commonwealth. London: Quiller, 1984.

Llewellyn, Stephen. "N.B. Speaker Faces Non-Confidence Vote; Liberal MLA Says Backroom Deal- Making Involving Tanker Malley has Weakened Respect for Legislature." New Brunswick Telegraph-Journal 27 Apr 2006, sec. News: A3.

Lloyd, Selwyn, Lord. Mr. Speaker, Sir. London: Cape, 1976.

May, Thomas Erskine. McKay, W.R.Cranmer, Frank. Erskine May's Treatise on the Law, Privileges, Proceedings, and Usage of Parliament. Uniform Title: Treatise on the Law, Privileges, Proceedings, and Usage of Parliament. 23rd ed. / editor, Sir William McKay; assistant editors, Frank Cranmer ... [et al. ed. London: LexisNexis UK, 2004.

Murray, John. "The Role of the Speaker and Political Reality - Paper Presented by the Hon. John Murray MP, Speaker of the Legislative Assembly of New South Wales." $33^{\mathrm{Rd}}$ Conference of Presiding Officers and Clerks. Brisbane, Queensland, Australia. www.anzacatt.org.au. 5 July 2008 <http://www.anzacatt.org.au/prod/anzacatt/anzacatt.nsf/ca3cb73640e4b7d4ca2567ee0016638b/56e7a77ded c3a67dca256d18001dd041!OpenDocument>.

New Brunswick. Elections New Brunswick. Unofficial Provincial By-Election Results. (Online). Fredericton, NB. Communications New Brunswick. 14 November 2005. Available: $<$ http://www.electionsnb.ca/03prov/05nov14/05nov14provbyresults-e.asp> [Accessed 30 May 2008]. 
---.---. Miramichi Bay de Vin Poll by Poll Results. (Online). Fredericton. Communications New

Brunswick. 18 Sept 2006. Available: <http://www.gnb.ca/elections/06prov/06provresultpage-

e.asp?PED=11> [Accessed 28 May 2008].

---. Legislative Assembly. Journal of Debates (Hansard)[Unofficial], 55th Assembly, 3rd session, Daily sitting 20, (7 April 2006). Fredericton, NB Queen’s Printer 2006.

---.---.---.---.--- Daily sitting 23, (13 April, 2006). Fredericton, NB Queen’s Printer 2006.

---.---.---.---.---.Daily sitting 40, (30 May, 2006). Fredericton, NB Queen’s Printer 2006

---.---.---------- Daily sitting 6, (14 December 2005). Fredericton, NB Queen’s Printer 2005

---.------.------- Daily sitting 10, (21 December, 2005). Fredericton, NB Queen’s Printer 2005

---.---.---.---.--- Daily sitting 29 ( 3 May 2006).Fredericton, NB Queen’s Printer 2006

---.---.. Journal of Debates (Hansard). 52nd Legislature 3rd Session, Vol. 9 (2 December 1994)

Fredericton, NB. Queen’s Printer, 2006

---.---.. Standing Rules of the New Brunswick Legislative Assembly. (Online) Fredericton, NB.

Queen’s Printer. Available: < $\underline{\text { http://www.gnb.ca/legis/publications/srules/srules-e.asp> [Accessed } 30 \text { June }}$

$\underline{2008]}$

------. Synoptic Report. 49th Parliament, 1st Session, Vol. 1 (12 March 1979) Fredericton, NB, Queen’s Printer,1979

---.. The Revised Statutes of New Brunswick, 1952, being a Revision and Consolidation of the Public Statutes of the Legislature of New Brunswick, Printed from the Roll Declared to be the Revised Statutes of New Brunswick, 1952, Pursuant to the Revised Statutes 1952 Act. Fredericton: Queen's Printer for the Province, 1953. 
Redlich, Josef. The Procedure of the House of Commons; a Study of its History and Present Form. Uniform Title: Recht Und Technik Des Englischen Parlamentarismus. English. New York: AMS Press, 1969.

Saskatchewan. Legislative Assembly. Debates and Proceedings (Hansard), 25th Assembly, vol 47 1st session, Daily sitting 8 (March 29th, 2004) Regina, SK, Queen’s Printer, 2004

"This Speaker must Resign." New Brunswick Telegraph-Journal 22 Apr 2006: A7.

White, Nathan. "I Won't Quit Speaker’s Job, Tanker Says; Embattled Speaker to Face NonConfidence Vote Today in Legislature." New Brunswick Telegraph-Journal 30 May 2006, sec. News: A1/A9. 


\section{Works Consulted}

Barisoff, Bill. "A Stronger Role For The Speaker In British Columbia." Parliamentarian 87.2

(2006): 122-4. Pais International.

Brown, Douglas. "The British Parliamentary System." Parliamentary Affairs Ii.3 (1949): 229-34.

Canada. Parliament. House of Commons. "House of Commons Debates, Official Report." (1951).

Chapman, Richard. "The Significance Of Parliamentary Procedure." Parliamentary Affairs Xvi.2 (1962): 179-87.

Cross, J. A. "Deputy Speakers And Party Politics." Parliamentary Affairs Xviii.4 (1964): 361-7.

Dicey, A. V. Introduction To The Study Of The Law Of The Constitution. London: Macmillan \& Co Ltd., 1965.

Ellis, Kathryn. "'The Squint From The Chair': Speaker Sir John Trevor, C. 1637-1717."

Parliamentary History 17.2 (1998): 198.

Forsey, Eugene A. University Of New Brunswick Law Journal; The Courts And The Conventions Of The Constitution. (Canada). Vol. 33. Carswell Company Ltd, 1984.

Fox, Paul. "Canada-A New Parliament With New Rules." Parliamentary Affairs X.4 (1956): 397404.

Hatsell, John. Precedents Of Proceedings In The House Of Commons; With Observations. South Hackensack, N.J: Rothman Reprints, 1971.

Heard, Andrew David. Canadian Constitutional Conventions : The Marriage Of Law And Politics. Toronto ; Oxford: Oxford University Press, 1991.

Laundy, Philip. The Office Of Speaker. London: Cassell, 1964. 
Livingston, Williams. "The Security of Tenure Of The Speaker Of The House Of Commons." Parliamentary Affairs Xi.4 (1957): 484-504.

Marleau, Robert Montpetit, Camille, And Canada. Parliament. House Of Commons. House Of Commons Procedure And Practice. Ottawa: House Of Commons, 2000.

Marshall, Geoffrey. Constitutional Conventions : The Rules And Forms Of Political Accountability. Oxford; New York: Clarendon Press; Oxford University Press, 1984.

---. "What Are Constitutional Conventions?" Parliamentary Affairs, Vol.38, Issue 1, P.33 38.1 (1985): 33.

Mclachlin, Beverley. "Unwritten Principles." 2005 Lord Cooke Lecture. Wellington, New

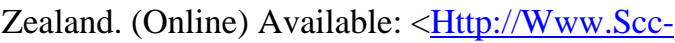

Csc.Gc.Ca/Aboutcourt/Judges/Speeches/Unwrittenprinciples_E.Asp> [10 December 2006]

New Brunswick. New Brunswick Commission on Legislative Democracy. Final Report and Recommendations. Fredericton, NB. Queen’s Printer, 2008 (Online) Available: http://www.gnb.ca/0100/FinalReport-e.pdf

---. Legislative Assembly. "Journal Of Debates (Hansard) ... Of The ... Legislative Assembly Of The Province Of New Brunswick." (1980).

---. "Journal Of Debates (Hansard) ... Of The ... Legislative Assembly Of The Province Of New Brunswick." Third Session Of The 52nd Legislature Of The Province Of New Brunswick 9 (1994) . ---. "Synoptic Report Of The Proceedings Of The Legislative Assembly Of The Province Of New Brunswick. Compte Rendu Des Débats De L'assemblée Législative De La Province Du NouveauBrunswick." (1895-1979).

Thorburn, Hugh. Politics In New Brunswick. Toronto: University of Toronto Press, 1961. 


\section{APPENDIX RELEVANT STANDING RULES}

6 In all cases not provided for in these Standing Rules, questions shall be decided by the Speaker or Chairman, whose decisions may be based on the usages and precedents of the House and parliamentary tradition in New Brunswick and other jurisdictions.

\section{PART III — THE FIRST MEETING OF THE HOUSE AND THE ELECTION OF A SPEAKER}

11(1) The House, on its first assembling after a general election, and at any other time as determined pursuant to subrule (2), shall make the election of Speaker the first order of business, which shall not be interrupted by any other proceedings.

11(2) In the case of a vacancy in the Office of Speaker, as a result of the death, resignation or otherwise of the incumbent to that Office, the House shall proceed to elect one of its Members to be Speaker.

11(3) No Minister of the Crown, nor leader of a recognized party in the House, shall be eligible for election to the Office of Speaker.

11(4) The election of a Speaker shall take precedence over all other business and no motion of any kind shall be accepted, and the House shall continue to sit, if necessary, beyond its ordinary time of daily adjournment, until a Speaker is elected and is installed in the Chair and if the House has continued to sit beyond its ordinary hour of daily adjournment, the Speaker shall thereupon adjourn the House until the next sitting, unless otherwise ordered.

11(5) For the purpose of electing a Speaker, the Clerk of the House, or in the absence of the Clerk of the House, another Clerk at the Table shall administer the election process and shall preside during the election of a Speaker.

11(6) During the election of a Speaker, the Clerk of the House shall not be permitted to entertain any question of privilege or point of order. 
11(7) During the election of a Speaker, there shall be no debate.

11(8) The election of a Speaker shall be conducted by secret ballot as follows:

(a) Any Member who does not wish to be considered for election to the Office of Speaker shall advise the Clerk of the House in writing no later than 5:00 o'clock p.m. on the day preceding the day in which the election of Speaker is expected to take place;

(b) Before the taking of the first ballot, the Clerk of the House shall affix in the lobby an alphabetical list of candidates and shall distribute that list to Members present in the Chamber;

(c) If there are two or more candidates for election to the Office of Speaker, ballot papers shall be provided to Members present in the Chamber, by the Clerks at the Table, prior to taking of the ballot;

(d) Members wishing to indicate their choice for the Office of Speaker shall print on the ballot paper, the first and last name of a candidate whose name appears on the list distributed pursuant to this Standing Rule;

(e) Members shall deposit their completed ballot papers in a box provided for that purpose at the Table;

(f) Once all Members wishing to do so have deposited their ballot paper, the vote shall be counted by the Clerks at the Table who, for this purpose, shall retire from the Chamber. The Clerk of the House, being satisfied as to the accuracy of the count, shall destroy the ballots together with all records of the number of ballots cast for each candidate, and all those persons present will in no way divulge the number of ballots cast for any candidate;

(g) If one candidate receives a majority of votes cast, the Clerk of the House shall announce in the Chamber the name of that Member as Speaker;

(h) If no candidate receives a majority of the votes cast, the name of the candidate having the least number of total votes shall be excluded from subsequent ballots;

(i) If every candidate receives the same number of votes, no name shall be excluded from the next ballot;

(j) For each subsequent ballot, the Clerk of the House shall prepare an alphabetical list of candidates and affix that list in the lobby, and distribute it to Members present in the Chamber;

(k) Subsequent ballots shall be conducted in the manner prescribed above, and the balloting shall continue, 
in like manner, until such time as a candidate is elected Speaker upon having received a majority of the votes cast;

(l) At any time after the result of the first ballot has been declared, but before the commencement of a second or subsequent ballot, a candidate may withdraw from the election, which shall then proceed as if such Member has not been nominated;

(m) If only one Member stands for election to the Office of Speaker, or at any stage a withdrawal pursuant to the above rules leaves only one candidate remaining, the Clerk of the House shall announce in the Chamber that candidate's name and without any vote declare that Member to be elected Speaker.

11(9) The election of a Speaker shall not be considered to be a question of confidence in the Government. (Amended: December 2, 1994.)

12 Within the first five days of the first session of each House, or whenever a vacancy occurs, the House shall elect two Deputy Speakers from among its members. [PROVISIONAL]

(Amended: February 18, 1992.) 


\section{PART IV - POWERS AND DUTIES OF THE SPEAKER AND OFFICERS OF THE HOUSE}

13 The Speaker shall preserve order and decorum and shall decide questions of order. In deciding a point of order or practice, the Speaker shall state the Standing Rule or other authority applicable to the case. No debate may be permitted on any such decision, and no such decision shall be subject to an appeal to the House.

14 The Speaker shall not vote or take part in any debate before the House or any Committee of the Whole House, except, when there is an equality of votes upon a division in the House, the Speaker shall cast the deciding vote and any reasons stated by the Speaker shall be entered in the Journal.

15 Whenever the Speaker is of the opinion that a motion offered to the House is contrary to the rules or privileges of the Legislature, the Speaker shall apprise the House thereof immediately, and may reserve any decision and subsequently state the reasons therefor, before putting the question.

16 The Deputy Speakers shall be Chairmen of the Committees of the Whole House. [PROVISIONAL]

17 Whenever the Speaker, from illness or other cause, finds it necessary to leave the Chair during any part of the sittings of the House on any day, the Speaker may call upon either of the Deputy Speakers or, in absence of the Deputy Speakers, upon any Member of the House to take the Chair and to act as Speaker during the remainder of that day, unless the Speaker resumes the Chair before the close of the sittings for that day. [PROVISIONAL]

(Amended: February 18, 1992.)

18 Whenever the House is informed by the Clerk of the unavoidable absence of the Speaker, either of the Deputy Speakers or in the absence of the Deputy Speakers, any Member appointed by the House shall take the Chair and shall perform the duties and exercise the authority of the Speaker in relation to all the proceedings of the House until the meeting of the House on the next sitting day, and so on from day to day on the like information being given to the House until the House otherwise orders. [PROVISIONAL] (Amended: February 18, 1992.)

19 The Speaker or the Chairman, after having called the attention of the House, or of the Committee, to the conduct of a Member who persists in irrelevance, or tedious repetition of arguments may direct the Member to discontinue speaking.

20(1) The Speaker or the Chairman shall order any Member or Members whose conduct is grossly 
disorderly to withdraw immediately from the House during the remainder of that day's sitting; and the Sergeant-at-Arms shall act on such orders as are received from the Chair in pursuance of this rule. But if, on any occasion, the Speaker or the Chairman deems that the powers under the previous provisions of this rule are inadequate, the Speaker or Chairman may name such Member or Members.

20(2) The provisions of Standing Rule 20(1) shall not apply to Chairmen of Standing or Select Committees.

21 Whenever a member has been named by the Speaker, or by the Chairman, immediately after the commission of the offence of disregarding the authority of the Chair, or of persistently and wilfully obstructing the business of the House by abusing the rules of the House, or otherwise, then, if the offence has been committed by such Member in the House, the Speaker shall forthwith put the question, on a motion being made by any Member, "That be suspended from the service of the House for a period of "; and, if the offence has been committed in a Committee of the Whole House, the Chairman shall forthwith suspend the proceedings of the Committee and report the circumstances to the House; and the Speaker shall on a motion being made forthwith put the same question, as if the offence had been committed in the House itself.

22 In the case of grave disorder arising, the Speaker or the Chairman may adjourn or suspend the House or a Committee without motion.

23(1) Strangers may be admitted to the galleries or to such other parts of the House as the Speaker sets apart for that purpose.

23(2) If any Member takes notice that strangers are present, the Speaker or the Chairman shall forthwith put the question, "Shall strangers be ordered to withdraw?", without permitting any debate or amendments.

23(3) When strangers are ordered to withdraw the business of the House shall be suspended until all strangers have withdrawn and strangers shall not be readmitted during the same day except upon motion which shall neither require notice nor be debated.

23(4) An order for strangers to withdraw does not apply to persons to whom seats in the press gallery have been assigned, except by decision of the House.

23(5) A stranger admitted to any part of the House or galleries who commits a misconduct or who does not withdraw when strangers are ordered to withdraw, shall be taken into custody or ejected from the Legislative Chamber or galleries by the Sergeant-at-Arms, as the Speaker may order. No persons so taken into custody shall be discharged without the special order of the House. 
24 The officers of the House are the Speaker, the Premier, and the Leader of the Opposition. The permanent officers of the House are the Clerk of the House, the Clerks Assistant and the Sergeant-at-Arms.

25(1) Subject to the directions of the Speaker, or the House, the Clerk shall

(a) be responsible for the safekeeping of the records and documents of the House;

(b) have direction over the Clerks Assistant and such clerks, official reporters, translators, stenographers, messengers, doorkeepers and pages as may be employed in connection with the House;

(c) be present at the Table in the Legislative Chamber during the sittings of the House;

(d) prepare and cause to be distributed the daily Journal, and Order and Notice Paper;

(e) cause a copy of the Journal for the preceding day to be available in the office of the Clerk and to such other offices as the Clerk may decide and a copy of the Order and Notice Paper for the day to be placed each morning on the Speaker's table and on each Member's desk;

(f) cause a copy of the Journal for the preceding day to be delivered to the office of the Lieutenant-

Governor;

(g) when the Committees have been appointed, cause a list thereof to be printed and posted in conspicuous places in the Legislature;

(h) at the conclusion of each session, cause the Journals to be indexed, published and bound;

(i) coordinate the broadcasting of live or recorded accounts of the proceedings of the House;

(j) perform such duties as are assigned by the Speaker.

25(2) The Clerks Assistant shall be present at the Table during the sittings of the House and shall assist the Clerk.

25(3) In the absence of the Clerk, the Clerk Assistant, or in the absence of the Clerk Assistant, such person as is appointed by the Speaker, shall perform the duties of the Clerk. 
26 The Sergeant-at-Arms is responsible for the safekeeping of the Mace, furniture and fittings of the House, subject to the orders received from time to time from the Speaker or the Clerk.

27 The Speaker may designate a Chaplain from time to time from amongst the religious community who shall read prayers before any business is entered upon. In the absence of the Chaplain, the Speaker or such person as is appointed by the Speaker shall read the prayers.

28 The permanent officers of the House shall complete the work remaining at the close of a session. 